Review

\title{
Agricultural Production in Qatar's Hot Arid Climate
}

\author{
Theodora Karanisa ${ }^{1, * \mathbb{D}}$, Alexandre Amato ${ }^{2}$, Renee Richer ${ }^{3}$, Sara Abdul Majid ${ }^{4}$, Cynthia Skelhorn ${ }^{2}$ \\ and Sami Sayadi ${ }^{1, *(1)}$
}

1 Center for Sustainable Development, College of Arts and Sciences, Qatar University, P.O. Box 2713 Doha, Qatar

2 Qatar Green Building Council, Qatar Foundation, Education City, P.O. Box 5825 Doha, Qatar; aamato@qf.org.qa (A.A.); cynthia.skelhorn@citrusbocc.com (C.S.)

3 Natural and Applied Sciences, University of Wisconsin-Green Bay 2420 Nicolet Drive, Green Bay, WI 54311, USA; richerr@uwgb.edu

4 Retro Technical Services, 204 Gate D1, Maarid Al Waab, Salwa Road, P.O. Box 22087 Doha, Qatar; sarahabdulmajid@yahoo.com

* Correspondence: tkaranisa@qu.edu.qa (T.K.); ssayadi@qu.edu.qa (S.S.)

check for updates

Citation: Karanisa, T.; Amato, A.; Richer, R.; Abdul Majid, S.; Skelhorn, C.; Sayadi, S. Agricultural Production in Qatar's Hot Arid Climate. Sustainability 2021, 13, 4059. https:// doi.org/10.3390/su13074059

Academic Editors: Mario D'Amico and Roberto Mancinelli

Received: 24 January 2021

Accepted: 31 March 2021

Published: 6 April 2021

Publisher's Note: MDPI stays neutral with regard to jurisdictional claims in published maps and institutional affiliations.

Copyright: (C) 2021 by the authors Licensee MDPI, Basel, Switzerland. This article is an open access article distributed under the terms and conditions of the Creative Commons Attribution (CC BY) license (https:/ / creativecommons.org/licenses/by/ $4.0 /)$.

\begin{abstract}
Agriculture has played an essential role in the provision of food and has been a major factor in overall economic development for societies around the world for millennia. In the past, agriculture in hot, arid countries like Qatar faced many challenges, the primary one being a dearth of water for irrigation. Historically this severely limited Qatar's economic development, which was based largely on resource exploitation, pearl fishing, and only more recently, on the exploitation of its oil and gas reserves which subsequently has led to Qatar's great wealth. This paper gives an overview of the recent evolution of Qatar's agricultural sector and investigates future trends that tackle the challenges of its hot arid climate and the limited availability of agricultural resources. Specifically, the review analyses Qatar's potential to develop a national food security strategy based on a significant expansion of food production in the country. We review recent policy actions implemented to address challenges in the food supply chain caused by a 3.5-year blockade imposed by the adjacent Arab Gulf States, discussing the renewed interest in the potential that an enhanced agricultural sector must provide some aspects of food security and the implications for policymakers that would logically ensue.
\end{abstract}

Keywords: agriculture; hot arid climate; Qatar food security; agricultural policy; urban food production

\section{Introduction}

The continuing development of agriculture plays a vital role globally in ensuring food security, improving nutrition, poverty eradication, and assists in the overall economic development of the world. Unsurprisingly, in 2018 agriculture was responsible for 4\% of global gross-domestic-product (GDP) [1]. However, there is a considerable range in the contribution that agriculture makes to national GDPs where the percentage contribution of agriculture to any one nation's GDP has an inverse relationship with the level of national economic development. For example, agriculture makes up 57.4\% of Sierra Leone's GDP, one of the world's least developed countries, but only 2.1\% of GDP in Australia, 0.6\% in the United Kingdom, and just $0.01 \%$ of Singapore's GDP. In the whole of the Middle East and North Africa (MENA) Region, agriculture contributes on average only $4 \%$ of national GDP but if the high-income oil and gas producing countries are excluded, then the percentage rises substantially to $9 \%$ [2].

Regardless of agriculture's relative economic importance, its role in feeding the world and providing food security means we ignore its strategic importance at our peril. Moreover, the advance of agricultural science which includes many different activities such as soil cultivation, tillage, harvesting, animal husbandry, and farming has enhanced world 
food production and enabled humanity to thus far escape a carrying capacity cycle of population growth leading to inevitable decline due to resource limitation [3]. Finally, agricultural products are not limited to food but include many other products like fibers, leather, timber, biofuels, etc. [4].

Agriculture practice, however, can be grossly unsustainable, depleting the planet's scarce resources of potable water (it accounts for $70 \%$ of potable water use worldwide) and can generate high levels of waste and pollution. Agriculture and forestry account for nearly $25 \%$ of total global anthropogenic greenhouse gas emissions, contributing approximately $25 \%$ of $\mathrm{CO}_{2}, 50 \%$ of $\mathrm{CH}_{4}$, and $70 \%$ of $\mathrm{N}_{2} \mathrm{O}[5,6]$. These are resultant from:

- the intensive use of energy derived from fossil fuels to power agricultural equipment, pumping water for irrigation, etc.;

- a similar use of fossil fuel derive energy for food and produce processing and transportation;

- extensive use of nitrogen-rich fertilizer; and

- livestock raised in either outdoor or indoor facilities.

The agricultural physical footprint covers approximately $50 \%$ of the global habitable land area, which has adversely affected biodiversity around the world leading to the extinction of numerous species [7]. Moreover, the impact of climate change on the worldwide agricultural sector will severely affect crop yields and increase the incidence of emergent infectious diseases and pests [8]. This will reintroduce Malthusian concerns about the ability of agriculture to support continued population growth, which, alarmingly, is projected to be over 9.5 billion people by 2050. It is also important to remember that even now $8.9 \%$ of the world's population have unmet dietary needs [1].

The state of Qatar is a small peninsula located in the Arabian Gulf and is among the richest countries globally with a GDP per capita of $\$ 125,006$ in 2017 [9]. Qatar is a highly urbanized country with $99.1 \%$ of its population living in urban areas [10]. It is largely dependent on food imports to feed its population of 2.88 million [9]. Although there has been an increase in Qatar's population (a yearly growth rate of 1.81\%) over the last 20 years, this will not be sustained as it has been primarily due to an expansion of immigrant workers (over $75 \%$ of the population) for the construction sector activity which is due to be severely curtailed in 2022, the year that Qatar hosts the FIFA World Cup. Thereafter, it is expected that an extensive hiatus in construction activity will ensue leading to a subsequent considerable reduction in Qatar's migrant workers' population and thus overall population.

Qatar imported approximately $90 \%$ of its food until 2017 [11] when neighboring Arab countries and their allies imposed an air, sea, and land blockade. The blockade raised national concerns regarding food security and led the country to explore alternative supply-side strategies and sources to satisfy the country's food demand. In response, food production in Qatar greatly increased and it was soon appreciated that agricultural production was both economically viable and a much more sustainable solution. Consequently, agriculture in Qatar can now be considered to be an emerging industry that provided $0.2 \%$ of Qatar's GDP in 2019 [12].

This paper provides an overview of the recent evolution of Qatar's growing agricultural sector and discusses its importance for the country's food security. Specifically, it examines:

- $\quad$ the challenges that local agricultural production faces (Section 3);

- the opportunities for the development of agriculture (Section 4); and

- agricultural policy initiatives that seek to increase production and thus provide greater national food security (Section 5).

\section{Importance of the Agricultural Sector in Qatar and Trends}

Qatar's agricultural sector has expanded in recent years due to the country's increased food demands caused by its rapid population growth and economic development. The number of active and operational farms has increased by $12.8 \%$ from 822 in 2010 to 916 in 2017 (see Table 1), although the number of registered farms in the country shows a small 
increase of $2.7 \%$ during the same period. Thus, farms that were previously registered in the Ministry of Municipality and Environment increased production. The active farms include plant production with both open field and greenhouse cultivation practiced and animal farms. Small-scale farms $(<20 \mathrm{ha})$ are usually oriented towards local market demand, whereas medium (20-100 ha) and large farms ( $>100 \mathrm{ha})$ also export produce like dates, cereals, eggs, milk, and milk products [13] to neighboring countries targeting other markets like Europe. The total arable area that could potentially be cultivated in Qatar is 65,000 ha and this area has been constant over the past few years [13]. However, the actual cultivated land area, which includes green fodder, date palms, fruits, vegetables, and cereals has increased by approximately 23\% from 2010 to 2019 (Table 1). In 2019, the agricultural and fisheries labor force was composed of $0 \%$ of Qatari and $1.4 \%$ of non-Qatari males out of the total labor force [14].

Table 1. Cultivated land area (ha), number of registered farms, number of active farms and food self-sufficiency index (self-sufficiency = local production/available for consumption \%) in Qatar (2010-2019) [13,15,16].

\begin{tabular}{ccccccccccc}
\hline & $\mathbf{2 0 1 0}$ & $\mathbf{2 0 1 1}$ & $\mathbf{2 0 1 2}$ & $\mathbf{2 0 1 3}$ & $\mathbf{2 0 1 4}$ & $\mathbf{2 0 1 5}$ & $\mathbf{2 0 1 6}$ & $\mathbf{2 0 1 7}$ & $\mathbf{2 0 1 8}$ & $\mathbf{2 0 1 9}$ \\
\hline Cultivated land area (ha) & 10,506 & 9020 & 10,532 & 12,610 & 11,663 & 11,571 & 11,021 & 11,590 & 13,203 & 12,907 \\
Number of registered farms & 1275 & 1281 & 1318 & 1340 & 1282 & 1290 & 1307 & 1310 & - & - \\
Number of active farms & 822 & 831 & 833 & 839 & 872 & 910 & 902 & 916 & - & - \\
Food self-sufficiency (\%) & 10.7 & 10.3 & 11 & 15.3 & 13.5 & 12.7 & 10.7 & 11.5 & - & - \\
\hline
\end{tabular}

Although agriculture is an emerging activity in Qatar, contributing to just $0.2 \%$ of GDP in 2017, the value-added as a contribution to GDP from the agriculture, forestry, and fisheries sector, increased from 145 million United States Dollars (\$) in 2010 to 305 million \$ in 2017, an increase of $110 \%$ over these seven years (see Figure 1). However, to put this trend into context, in 2017 the country imported 1.3 million tonnes of agricultural products with a value of approximately 1 billion $\$$ and exported 14,157 tonnes of produce from the sector with a value of 9.5 million $\$$ as shown in Figure 2. Agricultural produce is dominating the share in amount (tonnes) and consequently, value (\$) among fisheries and forestry produces, especially since there is no forestry activity in the country. Fisheries accounted for 33,841 tonnes out of 1.3 million tonnes in a total of agricultural products imports and 773 tons out of 14,157 tonnes in a total of exports for 2017, whereas the remaining share is for agricultural production which includes plant, meat, dairy products, and eggs [17]. Agricultural product imports increased by $43.9 \%$ in tonnes and $50 \%$ in value over the 5 years from 2012 to 2017 and follow Qatar's population increasing trend over this period, which was $24 \%$ from 2.2 million to 2.7 million [9].

Because of Qatar's limited resources and harsh climate, it has traditionally imported more than $90 \%$ of food requirements from more than 100 countries, like the Netherlands, Kenya, South Africa, New Zealand, India, etc. [11]. Consequently, Qatar has always been sensitive to the issue of food security and set up a National Food Security Program (QNFSP) in 2008 to reduce the state's reliance on food imports through self-sufficiency and domestic production [18]. Since the 2017 air and sea blockade imposed on Qatar by the same neighboring countries and their allies within the MENA region who supplied the bulk of Qatar's food requirement [11,19], the issue of food security has understandably become an acute national concern. On 5 June 2017, Saudi Arabia, the United Arab Emirates (UAE), Egypt, and Bahrain, all of which are neighboring countries and allies in the region, cut diplomatic and trade ties with Qatar and imposed a land, sea, and air blockade. The four countries claimed Qatar supported "terrorism", had close tights to Iran, and interfered in the internal affairs of their nations. Notably, before the blockade in 2017, $27.4 \%$ of Qatar's food imports came from Saudi Arabia and the UAE as well as $60 \%$ of dairy products. Moreover, $40 \%$ of food imports passed through Saudi Arabia [20,21]. The blockade ended on 4 January 2021. Subsequent to the blockade, Qatar rapidly developed relationships with many new food product suppliers. However, local food production was also rapidly prioritized, and the percentage of food produced within Qatar went up 
from $10.7 \%$ in 2016 to $11.5 \%$ in 2017 the same year as the blockade (Table 1). This was particularly true of perishable products such as vegetables and milk, which has nearly tripled $[15,22]$ since 2017. Self-sufficiency in many food products like meat, dairy products, and vegetables has increased from $15.2 \%$ in 2014 to $28 \%$ for vegetables in 2019 with a growth of 16 local varieties, while the Ministry of Municipality and Environment (MME) has targeted ambitious goals for 2023, reaching $70 \%$ self-sufficiency in vegetables, as shown at Figure 3. It is noteworthy that Qatar was greater than $100 \%$ self-sufficient for fresh dairy products and poultry in 2019 with $106 \%$ and $124 \%$, respectively (Figure 3).

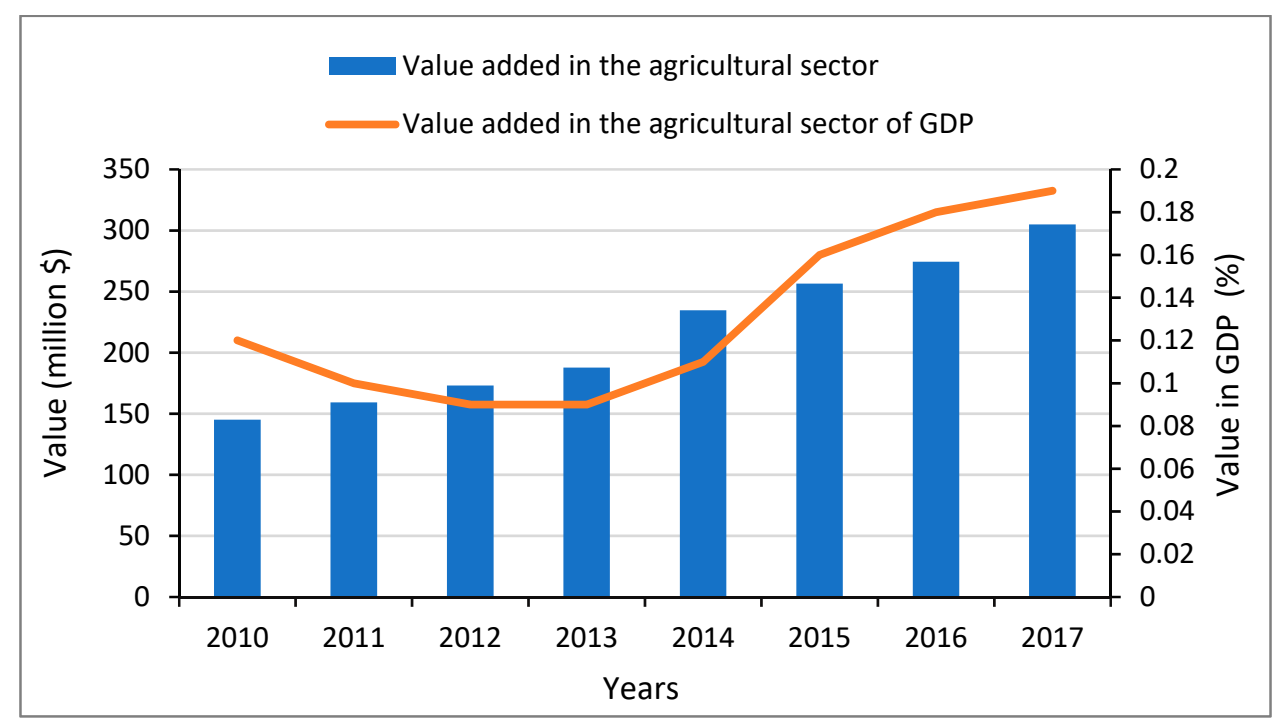

Figure 1. Value added (million \$) and value added of GDP (\%) of agriculture, forestry and fishery sector for the Qatari economy Qatar $(1 \mathrm{QR}=0.27 \$)(2010-2017)[16,17]$.

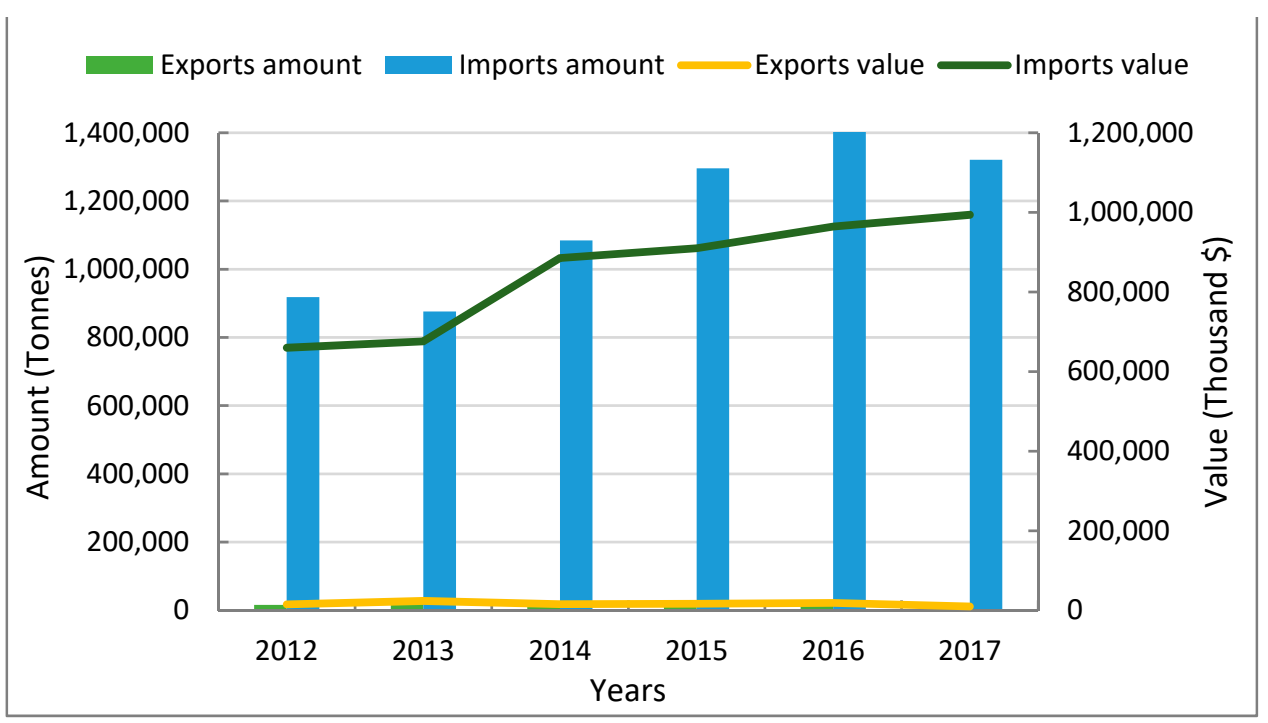

Figure 2. Exports and imports amount (tonnes) and exports and imports value (\$) of agricultural products in Qatar (1 QR = 0.27\$) (2012-2017) [17]. 


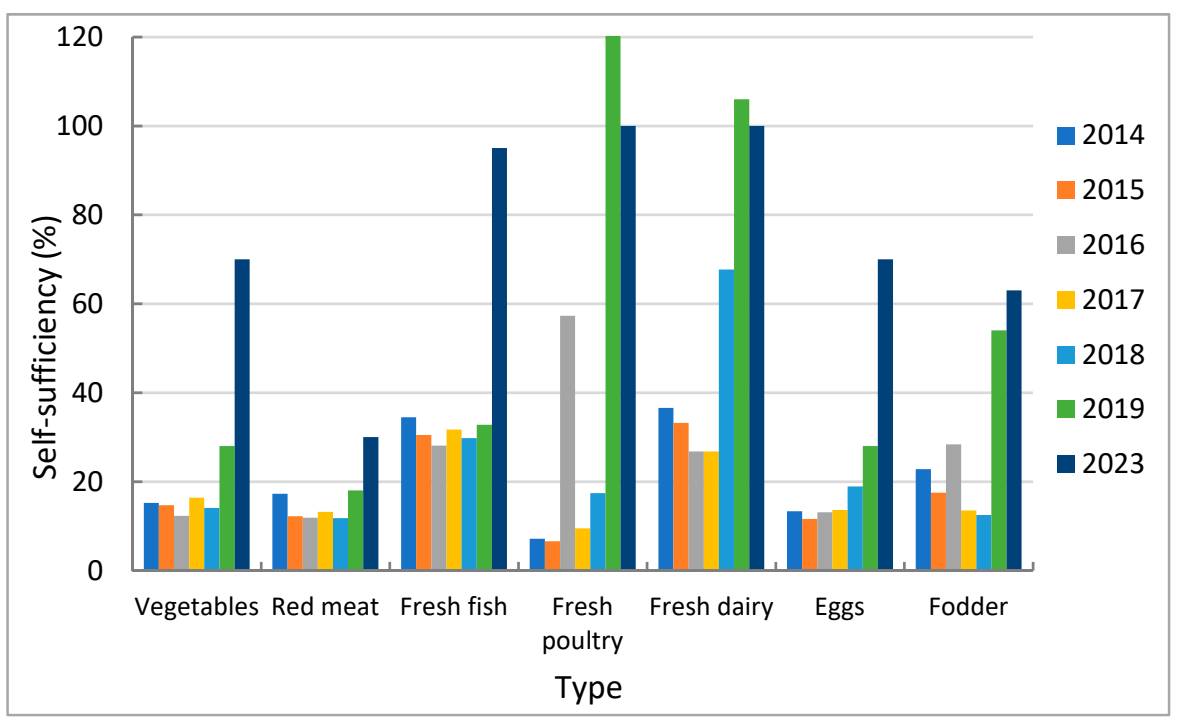

Figure 3. Self-sufficiency (self-sufficiency = local production/available for consumption $\%$ ) of major Figure 2014. [13,23,24].

Using modern production methods applied to both outdoor and indoor cultivation methods, local farms are making considerable efforts to improve their agricultural production. This also includes the rapid development of equipment and practices suitable for use in hot arid climates such as:

- greenhouse structures;

- efficient water-conserving irrigation techniques; and

- advanced cooling technologies to increase the shelf life of products.

These efforts have been remarkably successful, achieving high yields and meeting the goals for food security [23,25] set by MME. As a result, the greenhouse market in Qatar is growing, reaching a value of $\$ 97.9$ million in 2018; the market value is further expected to reach $\$ 216$ million by 2024 [26]. Greenhouse crop production uses both soil cultivation and hydroponic techniques, as the soilless cultivation systems have been developed as a sustainable solution to food production and food security. Hydroponic farming is considered more sustainable than traditional farming as it maximizes overall output and minimizes the use of space, soil, water, and other resources. More specifically, hydroponic crop production reduces the quantity of land required to produce, minimizes the use of harsh chemicals needed to fertilize soil while using around $70 \%$ less water, and produces a greater yield of fruits and vegetables in a shorter time [27]. Besides, aquaponic systems that combine hydroponics and aquaculture have the potential to tackle sustainability issues and reach food security targets in Qatar [28].

Several local companies are following organic farming principles as the demand for organic products is increasing with consumers becoming more aware of the benefits of locally grown organic produce and follow a healthier lifestyle. Moreover, some companies like Agrico Agricultural Development, apart from the sustainable farming methods that they follow, are applying circular economy principles, aiming to transform business processes into sustainable, closed-loop resource systems [29], in their waste management by composting and reusing the organic waste generated in the farm.

Qatar's market for organic products is growing and the organic packaged food and beverage consumption was estimated to have reached $\$ 14.4$ million within 2020 [30]. The number of organic farms and farmers' markets is also increasing in Qatar [31] and the key farms are shown in Table 2. Some farms hold international organic certifications like USDA Certification by Agrico Agricultural Development and IFOAM Certification by Al Safwa Farms. Although there are national legislation standards for the organic agricultural sector in Qatar, there is no national certification body to certify the organic farms. 
Table 2. Key farms following organic farming methods, year of establishment, and location in Qatar [32-38].

\begin{tabular}{ccc}
\hline Farm & Year of Establishment & Location \\
\hline Agrico Agricultural Development & 2011 & Al-Khor \\
Al Mustafawi Organic Vegetable Farm & 2014 & Umm Ammad \\
Al Safwa Farm & 1965 organic since 2012 & North of Doha \\
Al Sulaiteen Industrial Complex (SAIC) & 1998 & Umm Salal Ali \\
Global Farm & - & Umm Salal Ali \\
Jerry Smeih Farm & 1930 s & North West of Al-Khor \\
Torba Farm & $1900 \mathrm{~s}$ & Abu Thaylah region \\
\hline
\end{tabular}

\section{Challenges}

\subsection{Climate}

Qatar has a hot desert climate (BWh) according to Köppen's classification [39]. Hyperarid countries like Qatar, are characterized by sparse precipitation and high summer temperatures often experienced together with high humidity, high solar radiation, poor soil, and strong winds $[17,20]$. These environmental conditions present considerable problems for agricultural production and in Qatar agriculture has been traditionally limited to the months between October and April. Although, this period of production can be slightly extended for summer crops like melons, okra, and eggplants. Figure 4 shows the 10-year average temperatures over an annual cycle; starting from March temperatures start to increase, peaking in July and start to decline in August.

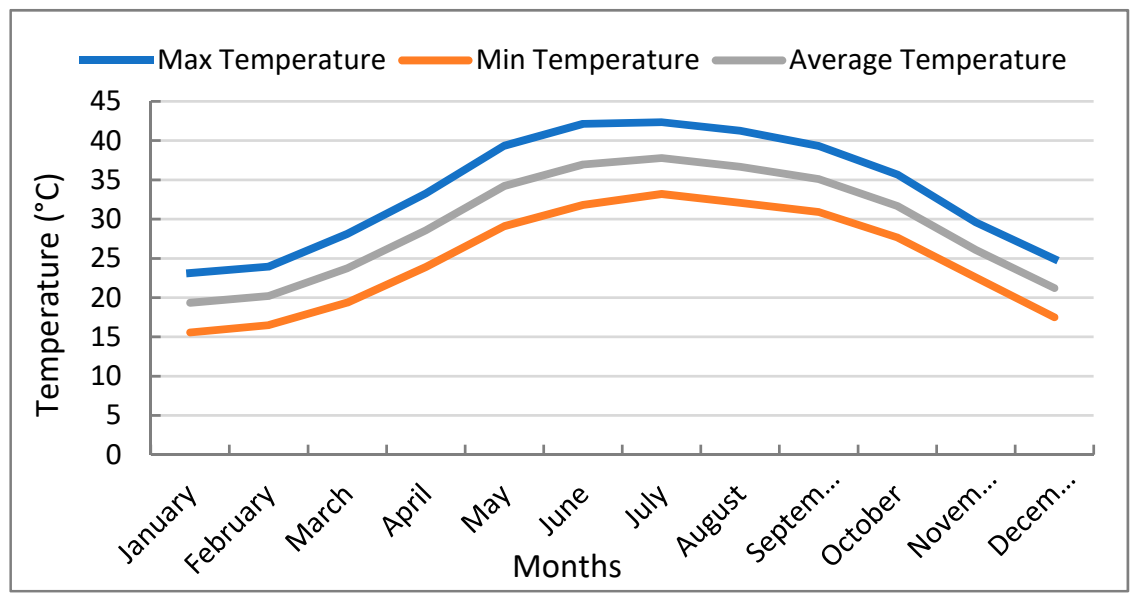

Figure 4. Average Temperature in Qatar over a period of 10 years (2009-2019) [40-42].

Humidity is very high as well, marking $42.5 \%$ average relative humidity around Doha International Airport in 2019 [40], with the period from November to February recording the highest rates, 60-65\% on average, as shown in Figure 5 for a 10-year period.

Doha Airport is located $4 \mathrm{~km}$ south of Qatar's capital, Doha with a latitude of $25.25 \mathrm{de}-$ grees and a longitude of 51.57 degrees, while its elevation is $11 \mathrm{~m}$ [43]. The land next to the airport will be developed in the future, as approximately 100 hectares will host an Airport City including a free trade zone, office and business park, hotels, and a retail mall. The small amount of precipitation that does fall occurs often in the winter and spring (specifically from October to May). In 2018, torrential rain caused extensive flooding across Qatar, as it received approximately the annual rainfall amount $(84 \mathrm{~mm})$ in one day. This rare phenomenon was not unprecedented as it was recorded previously in 2015 and tends to become more frequent, as sudden, and heavy scattered rain hit the country every year [44]. These events which were observed in November 2015 and October 2018 were extreme. It is noteworthy that the average monthly precipitation for October was $9.6 \mathrm{~mm}$ and $13.65 \mathrm{~mm}$ for November for the reference period of 2009-2019 (Figure 6). It rarely rains during the 
summer months. In Qatar, the rainfall takes the form of short (and often heavy) showers that can rapidly fill the wadis (riverbeds that are dry most of the year) and cause floods and is usually less than $100 \mathrm{~mm}$ per year. Figure 6 shows the average rainfall precipitation over a period of 10 years. During the month of November, the average precipitation is $17.15 \mathrm{~mm}$, which marks it as the month with the highest rainfall recorded over the past 10 years. Generally, from the month of October up to May (winter and spring), small amounts of precipitation are recorded; however, all year round is considered a dry season in Qatar as there is no rain season (Figure 7).

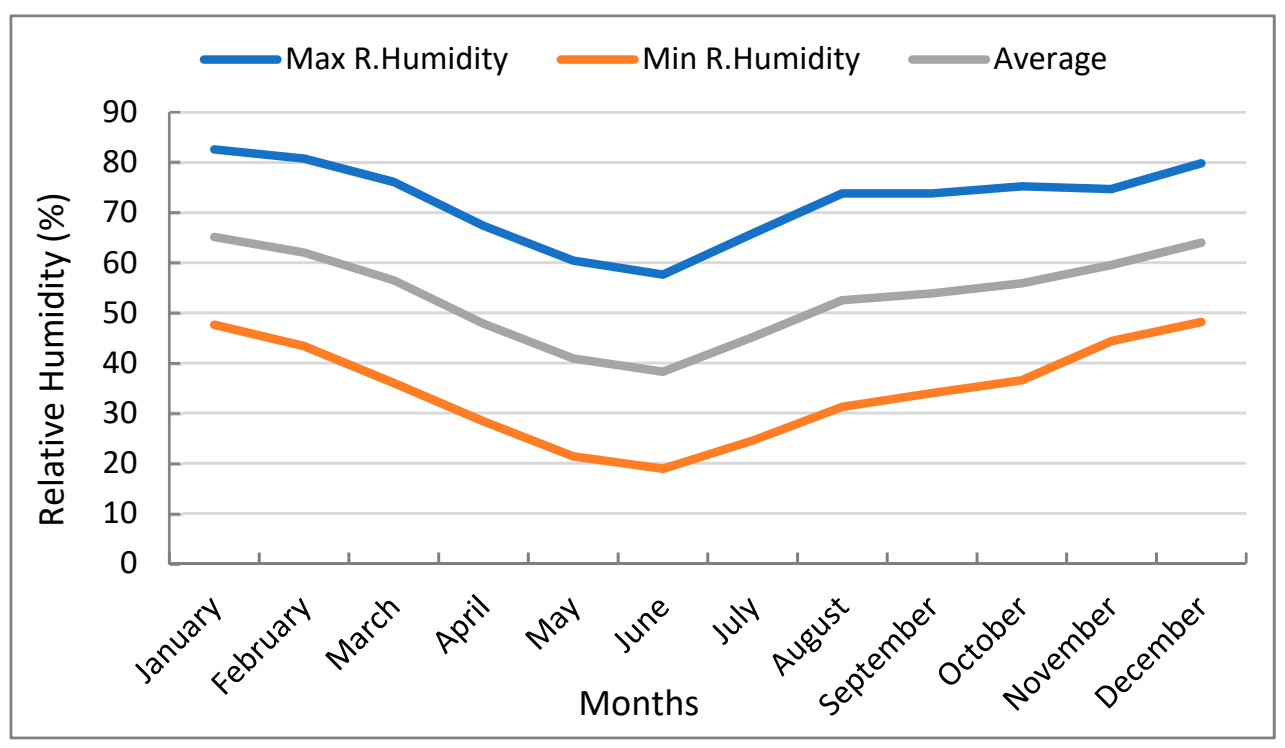

Figure 5. Average Relative Humidity in Qatar over a period of 10 years (2009-2019) [40-42].

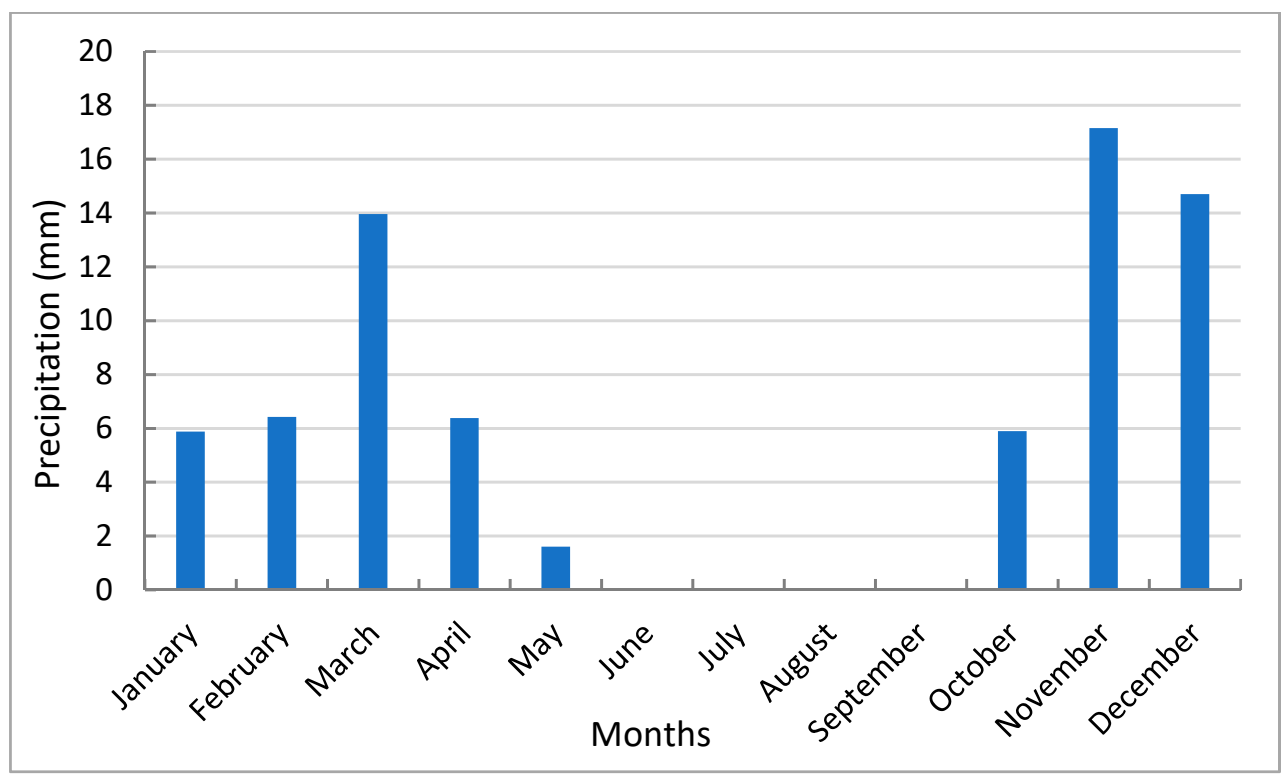

Figure 6. Average Rainfall Precipitation in Qatar over a period of 10 years (2009-2019) [41-43].

While the country's precipitation is low, the evapotranspiration is very high, estimated to $39 \mathrm{~mm}$ year $^{-1}$ in 2014, meaning significant amounts of water are lost through the crops and the soil surface, making optimal water management more crucial [45]. 


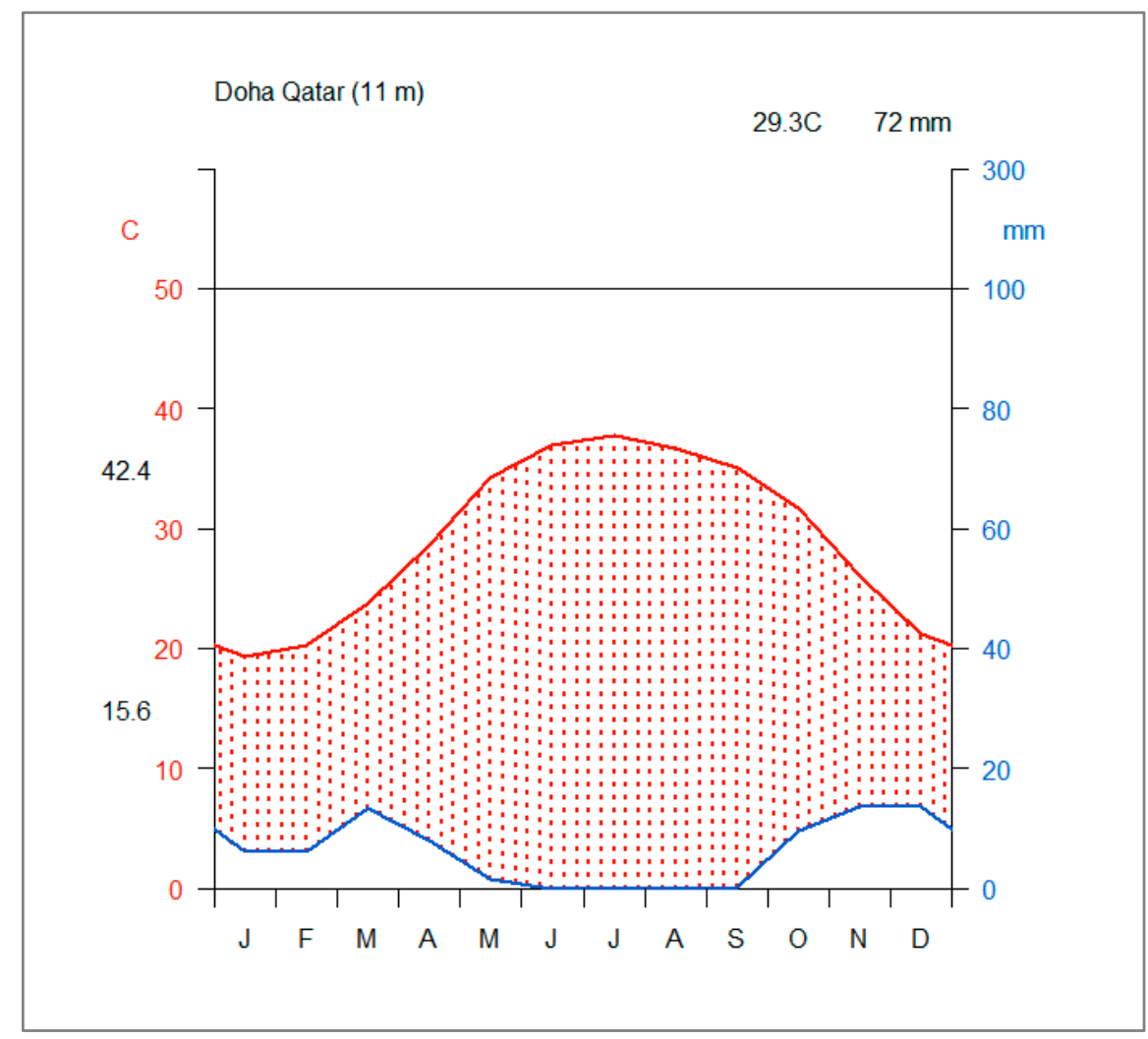

Figure 7. Walter and Lieth climate diagram for Doha, Qatar over a period of 10 years (2009-2019). Temperature $\left({ }^{\circ} \mathrm{C}\right)$ refers to average monthly mean temperature (red solid line) and precipitation $(\mathrm{mm})$ refers to average monthly precipitation (blue solid line) [40-43,46].

During all seasons in Qatar, the wind is always present. Figure 8 shows a 10-year average monthly wind speed over an annual cycle; the minimum wind speed is $6 \mathrm{~km}$ per hour and occurs in October. Strong winds and sandstorms occur often and contribute to the country's surface high evaporation rates, negatively impacting plant growth and thus food production. The effects of climate change must also be considered, as they are evident now $[47,48]$ and will increasingly affect agricultural production and thus food security. Several studies predict that in the Gulf region, annual temperature and rainfall patterns will change over the following decades [20,49-51]. Qatar's average annual temperature has already risen by $0.3{ }^{\circ} \mathrm{C}$ over the past 40 years and this average is expected to increase by $1.5-3^{\circ} \mathrm{C}$ by 2050 and by $2.3-5.9^{\circ} \mathrm{C}$ by $2100[52,53]$. The Middle East and North Africa (MENA) region is considered a climate change hot spot for predicted extreme events including heat and drought events [54]. For example, for a global mean increase of $2{ }^{\circ} \mathrm{C}$, MENA is predicted to rise by $3{ }^{\circ} \mathrm{C}$, and for a $4{ }^{\circ} \mathrm{C}$ global mean projections, MENA is predicted to rise by $8{ }^{\circ} \mathrm{C}$. Although there is predicted to be no significant change in Qatar's rainfall pattern in the medium term (2040-2069), a significant change is predicted at the end of the century (2080-2099) with a notable increase in annual rainfall $[55,56]$. Thus, increasingly erratic, and extreme precipitation patterns together with increasing extreme summer temperatures are predicted. These effects will likely shorten the growing season together with increasing the incidence of crop failure, reducing the production of both crop and livestock agriculture. 


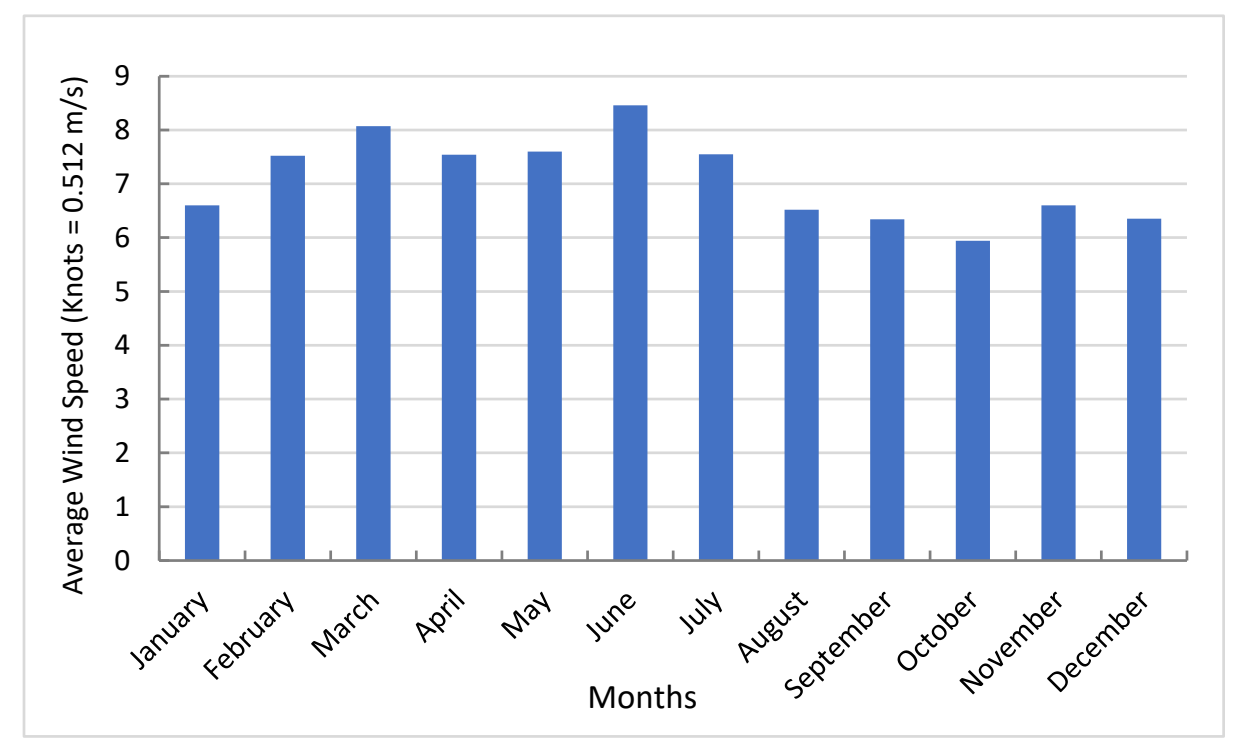

Figure 8. Average Wind Speed in Qatar over a period of 10 years (2009-2019) [40-42].

\subsection{Land Availability for Agriculture in Qatar}

Qatar is a small country with a surface area of approximately $11,628 \mathrm{~km}^{2}$ including a set of small islands [40]. It is about the same size as Rhode Island in the United States, or Malta and Luxemburg in Europe, or Hong Kong and Macau in Asia. Due to the relative scarcity of land available for agriculture, efficiently utilizing available land is a critical issue for ensuring national food security. There are however several competing interests and other limitations regarding land availability that require examination and further restrict the land available for traditional soil-based agriculture, which is assessed in this section.

\subsubsection{Soil}

The State of Qatar lies on arid soil, typically composed of a coarse texture, shallow soil, low water retention and slow soil formation and is therefore considered poor agricultural soil. The Atlas of Soils for the State of Qatar published by the Ministry of Municipal Affairs and Agriculture in 2005 [57] estimates that in Qatar, about 68,716 ha are suitable for arable cultivation and of this area a total of 23,903 hectares is already being used by farmers, leaving 44,813 hectares to potential farmland.

The most fertile and arable soils in the country are the locally known Rodah (depression) which are developed by limestone young colluvial deposits and they only account for $2.44 \%(27,620 \mathrm{ha})$ of the total country area. The Rodah soils are scattered in over 850 depressions along in Qatar with a size of a few to 60 ha and that is a limiting factor for large-scale soil farming [58]. Traditionally, agriculture has been most intensively practiced in the northern regions of Qatar where the soil and rain conditions are more conducive to crop production. Soils in Qatar's north natural depression tend to contain higher clay than that of soils located in central and southern Qatar, while soils with the highest sand content are in depressions in the south of the country [59]. Soils with larger clay content tend to be relatively more fertile as the clay improves the soils' organic content and structure [60]. That is also a reason why most of the farms in Qatar are located in the northern part of the country [61].

Likewise, these nutrient-rich depressions are also areas that support much of the native flora and fauna. Habitat loss because of increasing agricultural production could put at risk, the already imperiled native species which perform crucial ecosystem services. Unfortunately, traditional irrigation with groundwaters has resulted in the salination of soils in this area. In recent years, the State of Qatar has made advances in protecting key habitats and species, recognizing sustainable development as a key pillar underpinning 
the development goals of the country. However, the food security implications may put these important policy developments at risk.

\subsubsection{Land Use}

Land use in Qatar includes residential, commercial, and industrial, education and health, farming, sports, tourism and religion, transport and utilities, government and special use and some areas are vacant and/or under construction [62]. The areas close to Doha, such as the adjoining Al Rayyan Municipality, Al Wakra, and Umm Slal have already been developed with multiple land uses leaving surrounding areas sparsely used in Qatar in 2015 [63]. More specifically, the areas including farms, nursery plant farms, poultry, and animal farms (camel, sheep, goats, cows) were about $25 \%$ out of the total land so far under use in all Qatar in 2015 [61].

According to the OECD's report on the land cover for 2018, Qatar had approximately $0.2 \%$ tree cover, $0.4 \%$ shrubland, $0.5 \%$ sparse vegetation, $2.4 \%$ cropland, $4.3 \%$ artificial surfaces, $90.3 \%$ bare area and $1.1 \%$ inland water of the total country area, as shown in Figure 9 [64]. The bare area (90\%) includes the land use categories mentioned above, including the urban area, which was recorded as $421.17 \mathrm{~km}^{2}$ total in 2013 in the capital city of Doha [65].

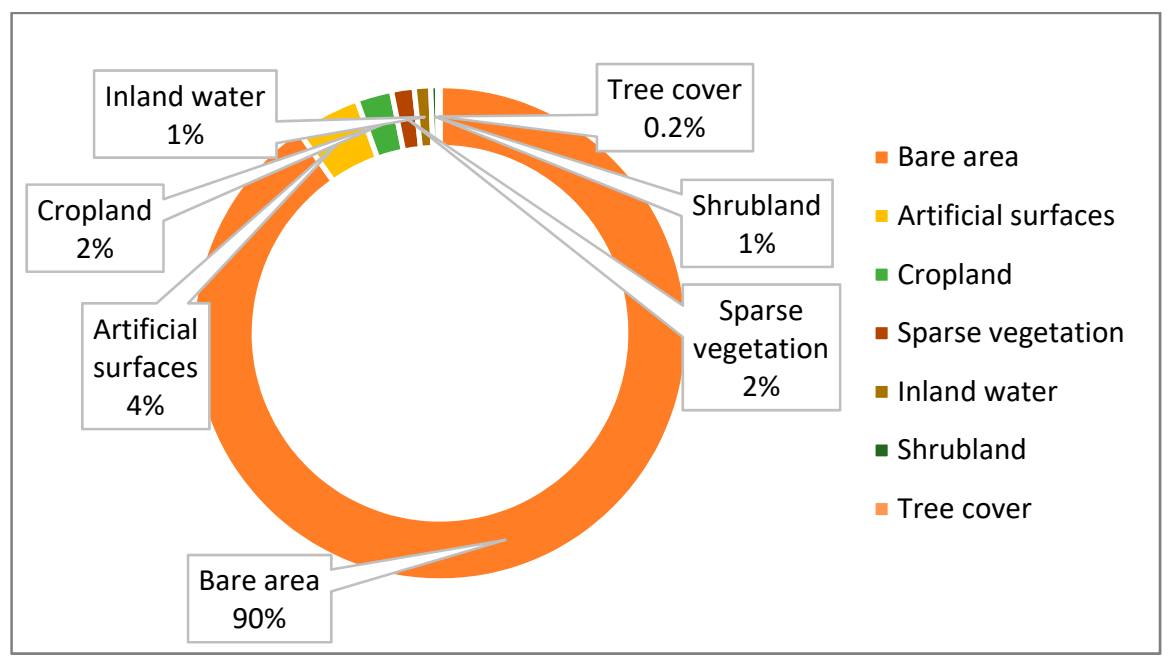

Figure 9. Land cover for Qatar in 2018 [64].

Qatar is a highly urbanized county with $99.1 \%$ of its population being urban in 2018 [9] and the majority living in the capital city of Doha and the surrounding suburbs. Urbanization in Doha has been increasing in recent years, with statistics indicating open spaces and the surroundings to have reduced from $76.8 \%$ in 1997 to $25.3 \%$ in 2010 [66]. This space reduction is attributed to the growing demand for residential, commercial, and recreational purposes. At the same time, there was an increase of $288.7 \%$ for built-up and a greater increase of $426.4 \%$ for recreational areas, respectively for the same period, indicating a positive planning attitude towards improving living standards in Doha and the surrounding areas. Within this context, urban agriculture could be incorporated in the urban planning strategies, as it provides a viable alternative for ensuring food security in Qatar while reducing pressure on ecosystems and the financial resources necessary to support agriculture in the hyper-arid country. The use of the urban environment for agriculture provides multiple benefits besides increasing food security. These include improving aesthetics, shading in the urban environment and also supporting mental health while increasing leisure activities, connection with nature and promotion of outdoor physical activity [67,68]. In Qatar, this could take the form of hydroponic or aquaponics gardens [69] urban orchards, edible landscaping and rooftop gardens or community gardens [70]. 


\subsubsection{Habitat Loss}

Qatar is a small country and land is scarce, thus any expansion of land-take for agriculture effectively results in habitat loss of the many native plant and animal species. Moreover, Qatar's terrestrial and coastal ecology is unique with a significant abundance of life-forms that have adapted to the harsh climate and although it is currently relatively undervalued, it should be preserved especially for future generations [71]. Many factors already adversely affect Qatar's native flora and fauna, like climate change, increasing land-take for urban development, and pollution, which together with the additional effects from a greatly expanded agriculture sector would produce considerable accumulative stress. Therefore, extensive agriculture practiced in Qatar's yet undeveloped hinterland would deplete this unique habitat's biodiversity and ecosystem services, endangering native flora and fauna. According to IUCN and the MME, there were 193 vulnerable and 20 endangered terrestrial and marine recorded species in Qatar in 2017 [72].

The unique sabkha environment, so dominant in Qatar supports a yet unexplored repository of unique microbial communities. Recent studies also suggest that sand dunes in Qatar support rich microbial life with an abundance of genes encoding sporulation and dormancy making the microbiome well-adapted to the exceptionally hyper-arid Qatari desert [73]. This wealth of biological and genetic diversity could be explored for a variety of bioactive compounds that could be potentially exploited for important innovative environmental engineering solutions

Furthermore, Qatar is obligated to the international community as signatories of several international treaties, covenants, environmental agreements, and conventions, such as:

- the Convention on Biological Biodiversity;

- the UN Convention to Combat Desertification; and

- the International Plant Protection Convention.

All these agreements obligate the country to protect its ecology even as it endeavors to advance its economy. Such international conventions emphasize protection of the unique biological diversity of Qatar which can only be maintained by promoting the habitat protections of these sensitive ecosystems. The continued development of agriculture in the State of Qatar may put other natural resources at risk, particularly if it is based on traditional, land-based agricultural systems.

It is a dilemma with food security and ecological conservation and restoration seemingly pushing in mutually exclusive directions. However, one possible solution to the need to provide the nation with food security but conserve and restore its unique ecology is to greatly expand urban food production.

This is potentially a very sustainable alternative that completely avoids habitat loss and resultant ecological damage, that supports ecosystem services, promotes sustainable development, and ensures an environment for long term habitation and tourism development.

\subsubsection{Tourism Growth}

The natural environment supports significant economic activity in the country. Tourism continues to develop in the State of Qatar, accounting for more than 5\% of GDP [74]. From the year 2012-2016, there was a $44 \%$ growth in tourism as a segment of GDP, a $22 \%$ increase in tourism jobs and a $45 \%$ increase in tourism investment [75]. Given the 2002 World Cup, Qatar may expect an even greater global tourism presence in the coming years [75]. In fact, tourism growth was greater than overall economic growth, one of five countries that saw such substantial growth in tourism [76]. The unique habitats and extreme desert environments with coastal shores are not only of biological value but also drive economic development, a diverse economy and hold a substantial economic value. The current drive for locally based agriculture to improve food security need not challenge habitat and species protections or risk natural environments that support tourism. 


\subsection{Water Availability}

The agricultural sector in Qatar utilizes 91\% of all renewable freshwater resources in the state [50]. Aquifers supply $36 \%$ of the country's water production, mostly in agriculture. Rainfall re-charges aquifers with an estimated annual amount of $80 \mathrm{~mm}$ (Figure 6). Although the water resources in the country are limited, in the period 2006-2016 the total water quantity (net of loss) increased from 447.27 to 890.24 million $\mathrm{m}^{3}$ per year. Qatar is highly dependent on seawater desalination for water production as desalination is the main source of total water production (61\%), followed by groundwater abstraction $(25 \%)$ in 2016. The greatest proportion of water uses, out of total produced water, were allocated for agricultural and domestic purposes, compared to the industry, commercial and government sectors. The agricultural sector consumes the largest quantities of freshwater compared to the other sectors, coming up to 296.3 million $\mathrm{m}^{3}$ total water used in 2016, as shown in Table 3. The main source of water in agriculture is the abstracted groundwater, followed by reused TSE. The abstracted groundwater must be desalinated before use in the hydroponic cultivation method, as it highly saline, which could negatively impact plant growth. The reasons for the high salinity concentrations of the groundwater are the stress caused by agriculture itself, urban development, and climate change [77]. The use of treated sewage effluent for agriculture and landscape irrigation purposes (5\%), started in 2004, as shown in Figure 10 and increased to 30\% in 2017 [78].

Table 3. Abstracted groundwater and Treated Sewage Effluent (TSE) (million $\mathrm{m}^{3}$ ) used in the agricultural sector (2010-2016) in Qatar [78].

\begin{tabular}{cccc}
\hline \multirow{2}{*}{ Year } & \multicolumn{3}{c}{ Agricultural Water Sources } \\
\cline { 2 - 4 } & Abstracted Groundwater (Million $\mathbf{~ m}^{\mathbf{3}}$ ) & TSE (Million $\mathbf{~ m}^{\mathbf{3}}$ ) & Total (Million $\mathbf{~ m}^{\mathbf{3}}$ ) \\
\hline 2010 & 228.88 & 32.28 & 261.16 \\
2011 & 229.47 & 41.98 & 271.45 \\
2012 & 230.05 & 58.71 & 288.76 \\
2013 & 230.55 & 55.23 & 285.23 \\
2014 & 230.64 & 64.92 & 294.92 \\
2015 & 230 & 61.7 & 291.7 \\
2016 & 230 & 66.29 & 296.29 \\
\hline
\end{tabular}

The use of TSE in irrigation is cheaper if compared to desalination [79]. It has been reported that reuse wastewater is priced at $\$ 0.28 / \mathrm{m}^{3}$, which is only half of the desalinated water cost [80]. Another report claimed that savings close to three folds can be realized when highly treated wastewater is utilized instead of desalinated water [81]. The energy required to desalinate water is also much higher than treating wastewater [82]. Researchers have reported that the energy required to treat wastewater is in the region of $0.8-1.2 \mathrm{kWh} / \mathrm{m}^{3}$, while the energy required to desalinate seawater could be around $4 \mathrm{kWh} / \mathrm{m}^{3}$ [83].

TSE use is a sustainable solution for agricultural irrigation as the aquifers are being depleted, the groundwater quality and quantity has been deteriorating because of overpumping and seawater intrusion and additionally, the desalination methods are emitting high $\mathrm{CO}_{2 \mathrm{e}}$ gases [84]. However, the use of TSE in agriculture is perceived negatively by farmers, as most of them view wastewater as unclean and unsafe [85]. Despite considerable investments in producing high-quality TSE using advanced treatment technologies in Qatar, there is hardly any demand due to various religious, social, and cultural factors that limit the use of treated wastewater in the country [86]. 


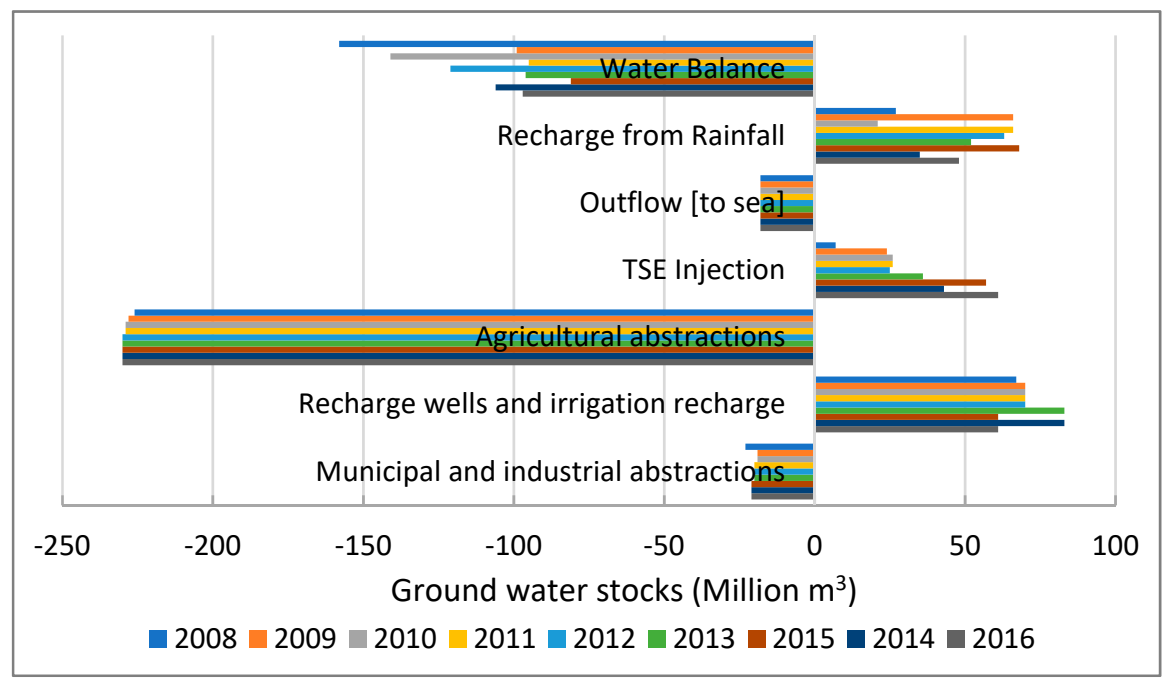

Figure 10. Qatar Water Balance (2008-2016) [87].

From the agronomic perspective, sustainable management practices to achieve sustainable groundwater use in Qatar include using water-efficient irrigation methods, replacing water-intensive crops with water-efficient crops, and enhancing awareness of water resources to the farmers. Moreover, the government could develop and apply certain water-use tariff structures to put a limit on irrational water use, and finally, enhance the rainfall infiltration to the aquifers [77].

Given current climate change scenarios that portend increasing temperatures and water scarcity, Qatar is uniquely placed to develop innovative technologies for a global agricultural market. As of December 2020, water is now being traded as a commodity on the New York Stock Exchange, stressing the increasing scarcity and value of these most important resources, and could make traditional, large scale irrigation practices economically unfeasible [87]. Continued development of indoor and outdoor agriculture that is not land-based, but hydroponic based, and suitable for incorporation into the urban environment, can better drive the development of agriculture in Qatar without risking recent developments in enhancing the natural environment.

\subsection{Supply Chain}

Qatar is the second-largest producer of ammonia, urea, and urea-formaldehyde among the Gulf countries. The fertilizer industry is a rapid-growing sector with a $9.4 \%$ average annual growth rate [88]. However, there are challenges in the supply chain for farmers and agricultural companies, as Qatar relies on imports for the necessary agricultural inputs like propagation material, plant protection, and some plant nutrition products. Reliance on external supply comes with the risk of supply shocks. A supply shock is a phenomenon where the external supply is cut off abruptly due to adverse events occurring in the supply countries. Since the nation has no control of the markets of its suppliers, it is impossible to predict when such disruption is likely to occur. In many cases, Qatar's agricultural sector is hit by input supply shocks which are aggravated by the country's over-reliance on external supply. Being a relatively small country compared to its trade partners, Qatar has low bargaining power when negotiating agreements for the supply of agricultural inputs. This causes over-pricing by its trade partners, which affects the final price of these inputs once they are in the country. Private farmers purchasing such supplies from the government after importation must bear the burden of these extra costs incurred during importation. Consequently, investment in the agricultural sector has become too expensive, hence deterring potential private investors. Thirdly, the instability created in Qatar's external supply chain by the blockade issued in 2017 by a few neighboring nations rocked the country. It is essential to understand that Qatar's main agricultural trade partners were neighbor nations, especially those in the UAE. The blockade reduced the country's 
import options significantly and created shortages in the supply of agricultural inputs from nations such as Saudi Arabia, Egypt, the UAE, and Bahrain. All these factors affect the nation's agricultural inputs supply chain by making it unstable, unpredictable, and unreliable. In the long run, therefore, the sector's growth is impaired immensely.

\section{Opportunities}

The emerging agriculture sector in Qatar holds great promise for striving towards improving national food security. Several opportunities for the development of this sector include exports, the use of greenhouse farming with hydroponics and aquaponics and the use of TSE for irrigation, permaculture techniques, and the use of saline crops.

\subsection{Exports}

The winter season in Qatar is very mild, with abundant sunshine resulting in a peak growing season that produces high-quality agricultural products. Thus, Qatar's winter climatic conditions offer an opportunity not only to satisfy local demand, but also for exporting fresh high quality agricultural products to countries in the Northern Hemisphere where severe winter conditions could prevent this. According to the Planning and Statistics Authority, in 2019 Qatar exported and re-exported products like dates, cereals, eggs, milk, and milk products as well as fish [13]. However, exports are still low compare to the imported products, as shown in Figure 2, with imports reaching the amount of 1,320,720 tonnes whereas exports were only 14.157 tonnes in 2017, a ratio of 1 to 93 [17].

\subsection{Greenhouse Production}

The traditional limitations to agriculture caused by the harsh summer climate and the limited extent of fertile soil could be rendered irrelevant with the adoption of soilless cultivation techniques, (e.g., cultivation in growth bags using soil substitutes such as cocopeat, rockwool, or perlite) and advanced greenhouse technologies. Greenhouse farming with soilless cultivation techniques such as hydroponics or aquaponics could potentially greatly increase food production in Qatar. This would be strategically preferable to utilize non-productive or marginal land unsuitable for soil cultivation [89].

It is imperative that the greenhouse design and technical equipment used should be suitable for the Qatari climate as standard methods and technologies used in other regions like Europe and the USA cannot be transferred to the Middle East due to the different climate control strategies and input availability [90]. According to researchers, to achieve an optimal thermal performance of greenhouses operating in hot and arid climates, the greenhouse should be oriented East to West and have an aspect ratio of 1:3, which will allow a lower temperature distribution along $80 \%$ of its length. This leads to efficient cooling while the most efficient design is the uneven span [91]. Greenhouse cultivation can ensure that crop production extends over the whole year and requires fewer inputs than open-field production. Moreover, agricultural business' diversification is increased through the provision of a greater variety of cultivated crops [27]. The advances of smart greenhouse technology (e.g., water-saving irrigation techniques and optimal resource management of many inputs like pest control and nutriments) enable crop production with minimal or greatly reduced inputs of energy, water and pesticides while maximizing crop yield [92]. Therefore, technological advancements in smart greenhouses enhancing productivity, water-saving irrigation techniques, and optimal resource management reducing the cost of production, offer an additional opportunity to expand domestic food production.

\subsection{Use of TSE for Irrigation}

The use of Treated Sewage Effluent (TSE) is an alternative water resource for irrigation in agriculture and landscaping, offering the opportunity for Qatar to produce food, without depleting the country's natural groundwater resources. Replacing desalinated potable water with TSE for irrigation also reduces cost, as TSE is cheaper than desalinated water and requires less energy to produce [79,82]. However, at present, traditional cultural beliefs 
and practices in the country have greatly restricted the use of TSE apart from irrigation for planting in urban landscaping and amenity areas. Even in parks and public green spaces, potable water is still predominantly used for irrigation. It is unsustainable to rely on exclusively using potable water for Qatar's growing agriculture sector. Fortunately, Sharia Law permits the use of TSE if it is safe and even "views wastewater reuse as part of the optimization of existing resources and as being supplementary; hence, misusing it is considered a disobedience to God" [93]. A national strategic consultation that includes policy makers, agriculturists, scientists and the public should review scientific data on the quality of treated wastewater and thus, revaluate existing customs and their limitations Other strategies of sustainable water usage are using Qatari native plants as a method of phytoremediation of wastewater [94] or harvesting rainwater in urban structures for later use.

\subsection{Halophytes and Saline Crops}

Agriculture in Qatar may also benefit from the cultivation and the development of non-traditional crops, such as halophytes and saline crops, which do not require freshwater and are tolerant to high salinity in water and soil. These crops have great potential to increase agricultural development and habitat restoration in areas affected by salinity [95]. Several researchers proposed sustainable halophyte farms using seawater for irrigation [96,97] or even fish waste that is nutrient-rich [98]. These would not only complement the hyper-saline ecosystem but would be economically valuable. Halophyte crop yields can equal yields of conventional crops grown using potable water, such as the forage crop alfalfa [98,99].

The critical factors in sustainable halophyte production are the choice of the appropriate halophyte species which should be economically and ecologically important as well as the adoption of optimal water management for irrigation [97]. Halophytes' salinity tolerance ranges from high to medium which subsequently allows seawater and/or brackish water to be used for agricultural irrigation while different species have diverse usages like food, fodder, fuels, medicines, building materials, fibers, and other utilitarian objects or even for soil and water remediation and for sequestering $\mathrm{CO}_{2}[99,100]$. Moreover, some halophytes can desalinate and fertilize the soils creating micro-habitats allowing the growth of other non-saline tolerant annual plants [98]. Researchers highlight the big potential for sustainable productivity of indigenous halophytic plant species such as the Avicennia marina and the Dunaliella salina on the landforms of saline sabkha along the southern and western Arabian Gulf [101].

Halophyte farms can also become a new biofuel source apart from food and feed sources, which can lead to new industries generating new jobs and income together with rational use of natural resources applicable for farms and consequently leading to sustainable living. Biofuel production from halophytes does not compete with traditional food crops for land and water, as it utilizes marginal lands and water sources while diversifying the use of halophytes. Moreover, the halophyte biofuel production system can offer multiple products like animal feed from the seed meal or ethanol production from straw [102].

According to a recent proposal by researchers an innovative, halophyte farm based on the land and the seacoast can integrate mangroves and seagrasses in its production units offering extra ecosystem benefits such as atmospheric carbon sequestration and reduced land-based marine pollution [96]. Mangroves, which can be found in large populations in Al Khor west of Qatar, can also be used for biofuel production, fodder and other economically important products thus creating additional jobs and profit [103].

Qatar has also the opportunity to expand halophyte research and development by creating an innovative "World Halophyte Garden" providing genetic material to the researchers and the private sector for commercial use. As stated by researchers, the Arab Gulf States provide an ideal location for the creation of such a genetic pool due to their 
plentiful saline ecosystems, the wide number of undeveloped native halophyte species and their limited freshwater availability [104].

Other researchers have investigated creating a 'saline agriculture' through the development of crops adapted to drought and salt using genetic engineering and traditional breeding tools [105]. Researchers in Florida found that inoculating snap peas with arbuscular mycorrhizal fungi increased yields at higher salinity levels [106], while researchers in Egypt found that inoculating tomato plants with the root endophytic fungus Piriformospora indica increased growth and yield under salt stress conditions [107].

\subsection{Urban Farming}

Urbanization in Qatar has been rapid, especially in Doha, where urban development increased by approximately fourfold between 1987 to 2013 [65]. The use of the urban environment for agriculture provides multiple benefits besides increasing food security through increasing food accessibility and food quality [108]. Researchers [108] underline numerous attributes to economic, social, and environmental development. Some of the social benefits are the creation of self-sufficient communities with access to fresher, healthier, local food. Urban lifestyle is improved in terms of leisure activities, places of relaxation, connection with nature, social interactions, and promotion of outdoor physical activity [68]. In addition, local economic development is enhanced by creating new jobs and increasing household income. Furthermore, urban agriculture provides urban residents with ecosystem services, such as water and air purification protection of urban biodiversity, reduction of food miles and cities' carbon footprint by recycling urban food waste [109]. Urban farming is currently also considered one of the solutions to climate change adaptation, as it can play a notable role in improving the urban climate and the heat island effect [110]. In Qatar urban agriculture could take the form of hydroponic or aquaponics gardens [69], urban orchards, edible landscaping and rooftop gardens or community gardens [70]. The introduction of permaculture practices could combine biodiversity conservation with food security. A detailed proposal on transforming Qatar University into a productive permaculture campus in the desert provides great inspiration [111]. The concept of food forests has been successfully achieved in harsh climates such as in the desert of Wadi Rum (Jordan) and near the Dead Sea by Geoff Lawton, whereby water resources are conserved, waste is composted, and the food forest becomes self-regenerative.

\subsection{Composting}

Compost can be used as a soil amendment in open field cultivation, as it improves soil physic-chemical properties and microbial biomass while enhancing the growth of plants even in saline soils [112]. It can also be used as a soil substitute in grow bags used in hydroponic cultivation. Food and green waste can be used for composting with multiple benefits. Food waste is the main waste component dumped at the landfill sites, where it converts into methane, carbon dioxide and other greenhouse gasses by anaerobic digestion, contributing significantly to global warming. Additionally, when food waste is placed in landfills, all the energy stored is lost like the not collected methane, thus a potential energy source is lost. These are valuable bioenergy sources that could have been utilized either for power production or converted into value-added products [113].

Qatar produces a considerable amount of food and green waste, and domestic waste production amounted to $1.2 \mathrm{~kg}$ per capita per day in 2015 [114]. Therefore, Qatar could and should use this valuable but currently neglected waste resource, turning it into compost for use for urban landscape and in the agricultural sector. This correspondingly reduces the amount of waste going to landfill as well as improving Qatar's environmental footprint, while satisfying high local demand for compost for gardening, and local horticultural business. 


\subsection{Organic Home Garden Initiatives}

While studies on home food production have not been conducted in Qatar, a study in Oman showed that home occupants were not encouraged due to harsh weather, excessive water bills and absence of horticultural knowledge as well as the prevalence of extensive paved in most urban plots [67]. However, it is increasingly considered valuable to spread awareness to Qatar's general population providing them with knowledge of how home gardening and food production can be practiced in arid environments. Demonstration projects are therefore considered highly important in this respect. For example, a community initiative named "Gharsa" is working to educate women about organic home gardening. Correspondence with the founder Mariam Al Dosari on 17 January 2021, advised that "Gharsa" provides educational courses, high quality seeds with good disease resistance, organic certified fertilizers and pesticides, and gardening tools. They have a strong social media presence and currently have over 100 actively participating home food gardens.

\subsection{Government Support}

The Qatari government through the Ministry of Municipality and Environment has launched several initiatives to help and further encourage the development of the agricultural sector [23]. For instance, there has been a concerted effort to supply greenhouse owners all over the country with low-cost technology needed to increase production, reducing the capital investment required for start-up agricultural businesses but increases production efficiency thereby raising profits. However, these initiatives are still at an early stage and their net effect has yet to be measured. Nonetheless, the government has more opportunities for boosting growth especially by partnering with private agricultural tech companies. Such partnering should ensure that there is sufficient infrastructure development for the optimal operation of the farms, as well as ensuring that there is the intellectual capacity for training a specialized labor force to support the increasing technological sophistication of agriculture as in the case for hydroponic cultivation techniques. The idea is to ensure that the small space available for farming in Qatar is used intensively, productively, and profitably. The year 2019 saw the Qatar government offer project lands to private investors. These lands were offered at an extremely subsidized fee to encourage agricultural business investment. This again is a big opportunity for increasing agricultural production as agricultural space is increasingly becoming expensive.

\section{Policy Implications}

In Qatar's 2030 National Vision, food security acknowledged as a national priority [115]. According to the World Food Security Index for 2019, Qatar ranks 13th globally. The indicators for this index include, affordability, availability, quality and food safety [50].

Qatar currently relies on imports and trade to meet the country's food demands. The government has launched various initiatives (see Table 4) to support and encourage the production of local produce, as it acknowledges that local agriculture can play a vital role in achieving a greater level of food security.

Table 4. Qatar agricultural initiatives towards Food Security [23,116-120].

\begin{tabular}{|c|c|}
\hline Initiative & Details \\
\hline Qatar National Food Security Strategy (2018-2023) & $\begin{array}{ll}\text { - } & \text { International trade and logistics } \\
\text { - } & \text { Enabler: Domestic markets } \\
\text { - } & \text { Domestic self-sufficiency (Figure 3) } \\
\text { - } & \text { Strategic reserves }\end{array}$ \\
\hline QNRF and MME Research project funding & $\begin{array}{l}\text { - } \quad \text { Food Security Research Calls } \\
\text { - } \quad 2 \text { cycles announced (2019-2020) }\end{array}$ \\
\hline $\begin{array}{c}\text { Greenhouse installation in local farms in } 2019 \text { by MME } \\
\text { and the Department of Agricultural Affairs }\end{array}$ & $\begin{array}{l}\text { - } \quad 350 \text { greenhouses installed in } 85 \text { local farms } \\
\text { - } \quad \text { Distribution of equipment and agricultural supplies }\end{array}$ \\
\hline
\end{tabular}


Table 4. Cont.

\begin{tabular}{|c|c|}
\hline Initiative & Details \\
\hline $\begin{array}{l}\text { Agricultural strategic investment projects ( } 34 \text { ) for } \\
\text { greenhouse vegetable production in } 2018 \text { by MME }\end{array}$ & $\begin{array}{l}\text { - } 100,000 \mathrm{~m}^{2} \text { area allocated for each project } \\
\text { - } \quad \text { Promote fresh vegetable production to achieve self-sufficiency } \\
\text { - } \quad \text { Involve the private sector in economic development }\end{array}$ \\
\hline ‘Daman' (guarantee) program & $\begin{array}{l}\text { - Launched in October } 2020 \text { and will continue through June } 2021 \\
\text { - The government will purchase local farm produce through a } \\
\text { pre-contract to facilitate the supply chain of the agriculture sector } \\
\text { Following a previous special program for the purchase of local } \\
\text { products in cooperation with Mahaseel company }\end{array}$ \\
\hline Qatar University & $\begin{array}{l}\text { Food and Water Security Program } \\
\text { - } \quad \text { Halophytes and saline crops } \\
\text { - } \quad \text { Soil Enhancement } \\
\text { - } \quad \text { Crop Cultivation } \\
\text { Water Reuse }\end{array}$ \\
\hline Greenhouse financing by Qatar Development Bank & $\begin{array}{l}\text { - Urban scale greenhouses } \\
\text { - Financing } 100 \% \text { of the value with a maximum of 70,000 QR } \\
\text { (19225.49 USD) } \\
\text { Develop the culture of agriculture and enhance self-sufficiency }\end{array}$ \\
\hline
\end{tabular}

The Qatar National Strategy for Food Security 2018-2023 aims to unify the efforts of the authorities in the country, optimazing natural resources to strengthen food security resilience against national emergencies, potential trade shocks and supply chain disruption. The Ministry of Municipality and Environment (MME) in Qatar has a Department dedicated to Agricultural Affairs, as well as a separate but complementary Livestock and Fisheries Department, both support research and development of food production in Qatar. Educational institutions in the country like Qatar University have also developed Food and Water Security Programs focusing on research areas like crop production including halophytes and saline crops, soil improvement and water reuse [116]. Qatar National Research Fund (QNRF), in partnership with the Ministry of Municipality and Environment (MME) has launched a second cycle of the Joint National Food Security Call, which in 2020 focused on the development of sustainable and dynamic food systems [117].

There are some private companies that support the marketing of local farmers' production, but currently no laws regulate the production and marketing of agricultural products. This lack of agricultural legislation is a big challenge for local farmers and agricultural companies. Legislation could set up a clear price-setting process and supervise quality certification more effectively than is undertaken now and this would greatly assist agricultural companies and instill market confidence.

It is important to note that the government decided to merge both short-term and long-term strategies in addressing the water issue. The short-term strategies are aimed at ensuring that the immediate situation including excessive water use by farmers is minimized. This will be done by the installation of water meters in the respective water wells. The long-term strategies will create a long-term impact in various areas such as the plant-selection patterns by farmers to fit the country's unique salty water conditions. There will also be a limitation on the number of wells that individual farmers can dig to preserve the country's underground water reserves. This will be done through aggressive and improved programs such as the Integrated Water Management Program under the Permanent Water Resources Committee (PWRC).

\section{Discussion and Conclusions}

This paper provides an overview of the evolution of the agricultural sector in Qatar and investigates its potential for future development. More precisely, it analyzes drivers of changes affecting Qatar's agriculture and food production systems and assesses their implications. 
Starting in the 1970s, Qatar had almost entirely based its economic growth on resource exploitation of the hydrocarbon sector, with agriculture being considered only as a "hobby", rather than an important economic activity. The real driver of change affecting Qatar's agricultural sector is the issue of food security, after the 2017 embargo (imposed by neighboring countries that made Qatar's government critically aware that it cannot rely on other countries to secure its food basket), and thus highlighted the need to produce in the country [11].

The factor that has most hindered the development of productive agricultural and horticultural systems in the past has been the availability of land, with suitable soils. This is a consequence of Qatar's harsh climate; it is in a hot arid zone [39] characterized by:

- $\quad$ sparse precipitation;

- $\quad$ high summer temperatures; together with high humidity in the late summer months that makes working outside very difficult;

- $\quad$ very high solar radiation;

- $\quad$ strong winds $[17,20]$; and

- limited freshwater availability for irrigation causing dependency on desalinated abstracted groundwater, and/or (more recently) on desalinated sea-water [78].

Moreover, Qatar is a small country occupying approximately $11,628 \mathrm{~km}^{2}$ [40] with a population density of 248 people per $\mathrm{km}^{2}$ [9] and the availability of its arable land [57] has competed with land-take from the country's rapid urban expansion over the last few decades [66]. It also has to compete with those sentiments outlined and extolled in the nation's 2030 Vision that seeks to preserve its unique but undervalued terrestrial, and coastal ecological systems. Lastly, apart from the above challenges, the agricultural sector regularly faces logistical challenges caused by the disruption of necessary key agricultural inputs by external factors such as supply-chain failure due to pandemics, international politics (blockades), etc.

However, modern greenhouse farming with soilless cultivation techniques that allow all-year-round crop production, such as hydroponics and aquaponics, have been used recently to overcome all the above limitations and considerably boost domestic food production [25-28,89-91]. Furthermore, these techniques are applicable to urban food production practices that inherently overcome the limitation and competition from urban land-take and the need for ecological conservation and habitat restoration (rewilding). Urban farming takes advantage of Qatar's low-density suburbs and benefits from the availability of large quantities of recycled water i.e., TSE for irrigation, as described below. It could be a very viable alternative for food production that has the further benefits besides increasing food security as it:

- reduces the pressure on Qatar's existing stressed ecosystems that provide important ecosystem services and the promotion of eco-tourism;

- reduces the large carbon footprint from importing plant-based produce (sometimes as far afield as North-Western Europe, if not further) [121];

- reduces the financial resources necessary to support food production in a hyper-arid country [79,82-86];

- improves urban aesthetics and urban shading, thus enhancing urban amenity spaces and improves mental health and well-being [68,108-110]; and

- generally, promotes sustainable development, and ensures an environment suitable for long-term habitation.

Qatar could use the considerable amount of food and green waste resource generated in the country [114] by turning it into compost for urban landscape projects and the agricultural sector. This would have the benefit of reducing environmental burdens while satisfying the high local demand for compost and export markets in the GEC region and accrue the consequent economic benefits. 
TSE is an alternative water resource for agricultural and urban landscaping irrigation. It does not deplete the country's natural groundwater resources while is cheaper than desalinated water and requires less energy to produce $[79,82]$.

Finally, there is also considerable potential for agriculture in Qatar to benefit from the development of non-traditional crops, such as halophytes and saline crops [97], seagrasses, and mangroves $[96,103]$ which do not require freshwater and are tolerant of high salinity in both water for irrigation and soil. These crops have the potential to increase agricultural development and habitat restoration in areas affected by salinity [95].

The research has also shown that despite the challenges faced by Qatar's agricultural sector, the government still has many opportunities to boost food production and thus promote greater food security. The past environmental limitations are no longer relevant, mainly due to technological advancements essentially the adaptation of tried and tested efficient agricultural production techniques to Qatar's unique circumstances. Moreover, if the agricultural sector switches from the use of fossil fuels to renewable energy, such as solar photovoltaic and/or solar thermal technologies that considerably reduce environmental impacts associated with the current generation of grid electricity, then agricultural production could be completed in a substantially more sustainable way than under current practices.

From an economic perspective, it is noteworthy that in recent years (2017), the government has begun encouraging more private investors to join the agricultural sector such as:

- financing the use of low-cost incentivized agricultural technology;

- facilitating the supply chain and marketing of the agriculture sector;

- $\quad$ supplying farms with modern greenhouses and essential agricultural equipment; and instigating innovative land projects for farmers [116-120].

Moving forward, the government must ensure that the improvement measures that are currently in place continue to be pursued. There should be consistency in government policy and interaction and these policies and interventions enhanced. It should also recognise that there is a still need to formulate more agriculture-friendly economic interventions if food security remains a strategically key goal. A national agricultural policy covering the production and marketing of agricultural products is more urgent than ever, as it will ensure supply and demand balance, price stability, product quality, product variety, and finally land and resources protection. While the national policy should cover the country's specific conditions, it should also be sufficiently flexible to address the particular circumstances of each agricultural business, addressing the differing resource availability and economic investment.

The paper has demonstrated that recent initiatives have had a positive impact on the growth of Qatar's agricultural sector and the country could become a model of future, modern agricultural production, and indeed also an exemplar for other countries with similar geo-climatic conditions.

Author Contributions: Conceptualization, T.K. and S.S.; methodology, T.K. and A.A.; data curation, T.K.; writing-original draft preparation, T.K., A.A., R.R. and S.A.M.; writing-review and editing, T.K., A.A., R.R., S.A.M., C.S. and S.S.; project administration, S.S.; funding acquisition, S.S. All authors have read and agreed to the published version of the manuscript.

Funding: The authors are grateful to the Qatar National Research Fund (QNRF) for funding and supporting the M-NEX Project (grant no. BFSUGI01-1120-170005) in Qatar. The M-NEX is a project of the Collaborative Research Area Belmont Forum (no. 11314551).

Institutional Review Board Statement: Not applicable.

Informed Consent Statement: Not applicable.

Data Availability Statement: Not applicable.

Conflicts of Interest: The authors declare no conflict of interest. 


\section{References}

1. World Bank Agriculture and Food. Available online: https://www.worldbank.org/en/topic/agriculture/overview (accessed on 24 November 2020).

2. World Bank Agriculture, Forestry, and Fishing, Value Added (\% of GDP). Available online: https://data.worldbank.org/ indicator/NV.AGR.TOTL.ZS?most_recent_value_desc=false (accessed on 9 September 2020).

3. FAO Coping with Water Scarcity in Agriculture a Global Framework for Action in a Changing Climate. Available online: http:/ / www.fao.org/fileadmin/user_upload/newsroom/docs/GlobalFRA-brochure.pdf (accessed on 24 November 2020).

4. Harris, D.R.; Fuller, D.Q. Agriculture: Definition and Overview. In Encyclopedia of Global Archaeology; Smith, C., Ed.; Springer: New York, NY, USA, 2014; pp. 104-113.

5. Montzka, S.A.; Dlugokencky, E.J.; Butler, J.H. Non- $\mathrm{CO}_{2}$ greenhouse gases and climate change. Nature 2011, 476, 46-50. [CrossRef] [PubMed]

6. IPCC. Climate Change 2014: Mitigation of Climate Change. In Contribution of Working Group III to the Fifth Assessment Report of the Intergovernmental Panel on Climate Change; Edenhofer, O., Pichs-Madruga, R., Sokona, Y., Farahani, E., Kadner, S., Seyboth, K., Adler, A., Baum, I., Brunner, S., Eickemeier, P., et al., Eds.; Cambridge University Press: Cambridge, UK; New York, NY, USA, 2014

7. Ritchie, H.; Roser, M. Land Use. Available online: https:/ / ourworldindata.org/land-use (accessed on 24 November 2020).

8. Sundström, J.F.; Albihn, A.; Boqvist, S.; Ljungvall, K.; Marstorp, H.; Martiin, C.; Nyberg, K.; Vågsholm, I.; Yuen, J.; Magnusson, $\mathrm{U}$. Future threats to agricultural food production posed by environmental degradation, climate change, and animal and plant diseases-A risk analysis in three economic and climate settings. Food Secur. 2014, 6, 201-215. [CrossRef]

9. Worldometer Qatar Population. Available online: https://www.worldometers.info/world-population/qatar-population/\#: \{\}: text $=$ The $\% 20$ current $\% 20$ population\%20of\%20Qatar,of\%20the \%20total\%20world\%20population (accessed on 31 August 2020).

10. FAO FAOSTAT-Qatar 2018. Available online: http:/ / www.fao.org/faostat/en/\#country/179 (accessed on 20 December 2020).

11. Miniaoui, H.; Irungu, P.; Kaitibie, S. Contemporary Issues in Qatar's Food Security. Middle East Insights No. 185; Middle East Institute: Singapore, 2018.

12. Planning and Statistics Authority in Qatar. Qatar in Competitiveness Yearbook, 2018; Planning and Statistics Authority: Doha, Qatar, 2018.

13. Planning and Statistics Authority in Qatar. Economic and Agricultural Statistics, 2019; Planning and Statistics Authority: Doha, Qatar, 2019.

14. Planning and Statistics Authority in Qatar. Labor Force Sample Survey: Annual Report 2019; Planning and Statistics Authority: Doha, Qatar, 2019.

15. Planning and Statistics Authority in Qatar. Economic and Agricultural Statistics, 2014; Planning and Statistics Authority: Doha, Qatar, 2014.

16. Planning and Statistics Authority. Environment Statistics Bulletin, 2015; Planning and Statistics Authority: Doha, Qatar, 2015.

17. Planning and Statistics Authority. Environment Statistics Bulletin, 2017; Planning and Statistics Authority: Doha, Qatar, 2017.

18. FAO Qatar and FAO. Capacity Building for Sustainable Natural Resource Management. Available online: http://www.fao.org/ 3/a-az577e.pdf (accessed on 26 November 2020).

19. Collins, G. Anti-Qatar Embargo Grinds Toward Strategic Failure. In Issue Brief no. 01.22.18; Rice University's Baker Institute for Public Policy: Houston, TX, USA, 2018.

20. Ben Hassen, T.; El Bilali, H.; Al-Maadeed, M. Agri-Food Markets in Qatar: Drivers, Trends, and Policy Responses. Sustainability 2020, 12, 3643. [CrossRef]

21. Ben Hassen, T.; El Bilali, H. Food Security in the Gulf Cooperation Council Countries: Challenges and Prospects. J. Food Secur. 2019, 7, 159-169. [CrossRef]

22. Planning and Statistics Authority in Qatar. Economic and Agricultural Statistics, 2018; Planning and Statistics Authority: Doha, Qatar, 2018.

23. Ministry of Municipality and Environment. Qatar National Food Security Strategy (2018-2023); Ministry of Municipality and Environment: Doha, Qatar, 2020.

24. Planning and Statistics Authority in Qatar. Economic and Agricultural Statistics, 2017; Planning and Statistics Authority: Doha, Qatar, 2017.

25. Enikeeva, K.; Khadra, C. Report on Trials Conducted in December 2019-December 2020; Agrico Qafco Yara Trial and Demonstration Center; Yara International: Doha, Qatar, 2019. Available online: https://www.qafco.qa/sites/default/files/Report\%20on\%20 Agrico\%20Qafco\%20Yara\%20trial\%20station.pdf (accessed on 24 November 2020).

26. Research and Markets Qatar Greenhouse Market: Industry Trends, Share, Size, Growth, Opportunity and Forecast 2019-2024. Available online: https:/ / www.researchandmarkets.com/reports/4828790/ qatar-greenhouse-market-industry-trends-share (accessed on 12 October 2020).

27. Sambo, P.; Nicoletto, C.; Giro, A.; Pii, Y.; Valentinuzzi, F.; Mimmo, T.; Lugli, P.; Orzes, G.; Mazzetto, F.; Astolfi, S.; et al. Hydroponic Solutions for Soilless Production Systems: Issues and Opportunities in a Smart Agriculture Perspective. Front. Plant Sci. 2019. [CrossRef]

28. Abusin, S.A.A.; Mandikiana, B.W. Towards sustainable food production systems in Qatar: Assessment of the viability of aquaponics. Glob. Food Sec. 2020, 25, 100349. [CrossRef] 
29. Fogarassy, C.; Finger, D. Theoretical and Practical Approaches of Circular Economy for Business Models and Technological Solutions. Resources 2020, 9, 76. [CrossRef]

30. Global Organic Trade Guide for Qatar. Qualitative Analysis. Available online: https://globalorganictrade.com/country/qatar (accessed on 3 August 2020).

31. ILOVEQATAR Qatar Guide. Available online: https://www.iloveqatar.net/guide/living/organic-vegetable-farms-and-marketsin-qatar (accessed on 28 July 2020).

32. Torba Farms about Torba. Available online: https:/ / farmersmarket.qa/about/ (accessed on 28 July 2020).

33. Jerry Smeih Farm. Available online: http:/ / www.jerrysmeih.com/ (accessed on 28 July 2020).

34. Agrico Agricultural Development about Agrico. Available online: http:/ / www.agrico.qa/ (accessed on 28 July 2020).

35. Al Sulaiteen Agricultural about Us. Available online: http:/ / saic.com.qa/saic/ (accessed on 28 July 2020).

36. Al Mustafawi about Us. Available online: http:/ / www.mustafawiorganicvegetable.com/page6.aspx (accessed on 28 July 2020).

37. TimeOutDoha Al Safwa Farm in Qatar. Available online: https:/ /www.timeoutdoha.com/community/features/61470-al-safwafarm-in-qatar (accessed on 28 July 2020).

38. Global Farm for Agricultural Supplies Homepage. Available online: https:/ / farm-640.business.site/ (accessed on 28 July 2020).

39. Kottek, M.; Grieser, J.; Beck, C.; Rudolf, B.; Rubel, F. World Map of the Köppen-Geiger climate classification updated. Meteorol. Z. 2006, 15, 259-263. [CrossRef]

40. Planning and Statistics Authority in Qatar. Physical and Climate Features Statistics, 2019; Planning and Statistics Authority: Doha, Qatar, 2019.

41. Planning and Statistics Authority in Qatar. Physical and Climate Features Statistics, 2014; Planning and Statistics Authority: Doha, Qatar, 2014.

42. Planning and Statistics Authority in Qatar. Physical and Climate Features Statistics, 2012; Planning and Statistics Authority: Doha, Qatar, 2012.

43. Civil Aviation Authority in Qatar (Meteorological Department). Climate Data, 2021; Civil Aviation Authority: Doha, Qatar, 2021.

44. Flood List Qatar-Flash Floods after Years' Worth of Rain in One Day. Available online: https://floodlist.com/asia/ qatar-floodsoctober-2018 (accessed on 30 November 2020).

45. Issaka, A.I.; Paek, J.; Abdella, K.; Pollanen, M.; Huda, A.K.S.; Kaitibie, S.; Goktepe, I.; Haq, M.M.; Moustafa, A.T. Analysis and Calibration of Empirical Relationships for Estimating Evapotranspiration in Qatar: Case Study. J. Irrig. Drain. Eng. 2017, 143, 2. [CrossRef]

46. Hartmann, K.; Krois, J.; Waske, B. E-Learning Project SOGA: Statistics and Geospatial Data Analysis; Department of Earth Sciences, Freie Universitaet Berlin: Berlin, Germany, 2018.

47. Wiebe, K.; Robinson, S.; Cattaneo, A. Chapter 4-Climate Change, Agriculture and Food Security: Impacts and the Potential for Adaptation and Mitigation. In Sustainable Food and Agriculture; Campanhola, C., Pandey, S., Eds.; Academic Press: Cambridge, MA, USA, 2019; pp. 55-74. [CrossRef]

48. Anderson, R.; Bayer, P.E.; Edwards, D. Climate change and the need for agricultural adaptation. Curr. Opin. Plant Biol. 2020, 56, 197-202. [CrossRef]

49. Elasha, B.O. Mapping of Climate Change Threats and Human Development Impacts in the Arab Region; United Nations Development Programme; Arab Human Development Report; Research Paper Series; Regional Bureau for Arab States: New York, NY, USA, 2010.

50. Alhaj, M.A.; Mohammed, S.; Darwish, M.; Hassan, A.; Al-Ghamdi, S.G. A review of Qatar's water resources, consumption and virtual water trade. Desalin. WATER Treat. 2017, 90, 70-85. [CrossRef]

51. Cheng, W.L.; Saleem, A.; Sadr, R. Recent warming trend in the coastal region of Qatar. Theor. Appl. Climatol. 2017, 128, 193-205. [CrossRef]

52. Planning and Statistics Authority. Qatar National Development Strategy, 2018-2022; Planning and Statistics Authority: Doha, Qatar, 2018.

53. Sowers, J.; Vengosh, A.; Weintha, E. Climate change, water resources, and the politics of adaptation in the Middle East and North Africa. Clim. Chang. 2011, 104, 599-627. [CrossRef]

54. Waha, K.; Krummenauer, L.; Adams, S.; Aich, V.; Baarsch, F.; Coumou, D.; Fade, M.; Hoff, H.; Jobbins, G.; Marcus, R.; et al. Climate change impacts in the Middle East and Northern Africa (MENA) region and their implications for vulnerable population groups. Reg. Environ. Chang. 2017, 17, 1623-1638. [CrossRef]

55. Al Mamoon, A.; Joergensen, N.E.; Rahman, A.; Qasem, H. Design rainfall in Qatar: Sensitivity to climate change scenarios. Nat. Hazards 2016, 81, 1797-1810. [CrossRef]

56. Al Mamoon, A.; Rahman, A.; Joergensen, N.E. Assessment of Climate Change Impacts on IDF Curves in Qatar Using Ensemble Climate Modeling Approach. In Hydrology in a Changing World: Challenges in Modeling; Singh, S.K., Dhanya, C.T., Eds.; Springer Water, Springer: Cham, Switzerland, 2019. [CrossRef]

57. Ministry of Municipal Affairs and Agriculture. The Atlas of Soils for the State of Qatar; Ministry of Municipal Affairs and Agriculture: Doha, Qatar, 2005.

58. Al Yousef, A.H.; El Sharief Abdalla, O.A.; Akbar, M.A. Progress Report for the National Report of the State of Qatar on the UNCCD Implementation; State of Qatar, Ministry of Municipal Affairs \& Agriculture, Department of Agricultural \& Water Research, Soil Research Section: Doha, Qatar, 2000. 
59. Al Mamoon, A. Rainfall Analysis under Changing Climate Regime in Qatar. Ph.D. Thesis, Western Sydney University, Sydney, Australia, 2018.

60. Johannes, A.; Matter, A.; Schulin, R.; Weisskopf, P.; Baveye, P.C.; Boivin, P. Optimal organic carbon values for soil structure quality of arable soils. Does clay content matter? Geoderma 2017, 302, 14-21. [CrossRef]

61. Planning and Statistics Authority in Qatar. Land Use-Agriculture \& Green Areas 2015. Available online: https:/ /psaqatar.maps arcgis.com/apps/webappviewer/index.html?appid=5d0b5f76614b42d38c220761a315da5f (accessed on 4 January 2021).

62. Planning and Statistics Authority in Qatar. Broad Land Use Categories by Zone. Available online: https:/ / psaqatar.maps.arcgis. com/apps / webappviewer/index.html?appid=55bcf88a0c6840b6acdca016674eac67 (accessed on 4 January 2021).

63. Planning and Statistics Authority in Qatar. Land Used Share by Zone. Available online: https://psaqatar.maps.arcgis.com/apps/ webappviewer/index.html?appid=ce4c6028b92b4b808f06296b0eb710d4 (accessed on 4 January 2021).

64. OECD Stat Land Cover in Countries and Regions 2018. Available online: https://stats.oecd.org/Index.aspx?DataSetCode= LAND_COVER\# (accessed on 3 January 2021).

65. Shandas, V.; Makido, Y.; Ferwati, S. Rapid Urban Growth and Land Use Patterns in Doha, Qatar: Opportunities for Sustainability? Eur. J. Sustain. Dev. Res. 2017, 1, 11. [CrossRef]

66. Hashem, N.; Balakrishnan, P. Change analysis of land use/and cover and modelling urban growth in Greater Doha, Qatar. Ann. GIS 2015, 21, 233-247. [CrossRef]

67. Al-Mayahi, A.; Al-Ismaily, S.; Gibreel, T.; Kacimov, A.; Al-Maktoumi, A. Home gardening in Muscat, Oman: Gardeners' practices, perceptions and motivations. Urban For. Urban Green. 2019, 38, 286-294. [CrossRef]

68. Orsini, F.; Kahane, R.; Nono-Womdim, R.; Gianquinto, G. Urban agriculture in the developing world: A review. Agron. Sustain. Dev. 2013, 33, 695-720. [CrossRef]

69. Goddard, S.; Al-Abri, F.S. Integrated aquaculture in arid environments. JAMS 2019, 23, 52-57.

70. Li, B.B.; Philpott, S.M.; Jha, S. The future of urban agriculture and biodiversity-ecosystem services: Challenges and next steps. Basic Appl. Ecol. 2015, 16, 189-201.

71. Richer, R. Conservation in Qatar: Impacts of Increasing Industrialization. SSRN Electron. J. 2009. [CrossRef]

72. Planning and Statistics Authority in Qatar. Environment Statistics Chapter 11 for the State of Qatar 2018; Planning and Statistics Authority: Doha, Qatar, 2018.

73. Abdul Majid, S.; Graw, M.F.; Chatziefthimiou, A.D.; Nguyen, H.; Richer, R.; Louge, M.; Sultan, A.A.; Schloss, P.; Hay, A.G. Microbial Characterization of Qatari Barchan Sand Dunes. PLoS ONE 2016, 11, e0161836. [CrossRef] [PubMed]

74. Wise, N.; Harris, J. Sports events, tourism, development and regeneration: A perspective from gulf states of Abu Dhabi, Dubai and Qatar. In Sport, Events, Tourism and Regeneration; Wise, N., Harris, J., Eds.; Routledge: Abingdon, UK, 2017 ; pp. 9-23.

75. Domareski Ruiz, T.C.; Chim Miki, A.F.; Dos Anjos, F.A. Competitiveness, Economic Legacy and Tourism Impacts: World Cup. Investig. Turísticas 2019, 17, 49-70. [CrossRef]

76. Sofronov, B. The economic impact on global tourism. Ann. Spiru Haret Univ. Econ. Ser. 2017, 17, 127-139. [CrossRef]

77. Ahmad, A.Y.; Al-Ghouti, M.A. Approaches to achieve sustainable use and management of groundwater resources in Qatar: A review. Groundw. Sustain. Dev. 2020, 11. [CrossRef]

78. Planning and Statistics Authority in Qatar. Water Statistics in the State of Qatar, 2017; Planning and Statistics Authority: Doha, Qatar, 2017.

79. Jasim, S.Y.; Saththasivam, J.; Loganathan, K.; Ogunbiyi, O.O.; Sarp, S. Reuse of Treated Sewage Effluent (TSE) in Qatar. J. Water Process. Eng. 2016, 11, 174-182. [CrossRef]

80. Côté, P.; Siverns, S.; Monti, S. Comparison of Membrane-based Solutions for Water Reclamation and Desalination. Desalination 2005, 182, 251-257. [CrossRef]

81. Missimer, T.M.; Maliva, R.G.; Ghaffour, N.; Leiknes, T.; Amy, G.L. Managed Aquifer Recharge (MAR) Economics for Wastewater Reuse in Low Population Wadi Communities, Kingdom of Saudi Arabia. Water 2014, 6, 2322-2338. [CrossRef]

82. Siddiqi, A.; Anadon, L.D. The water-energy nexus in Middle East and North Africa. Energy Policy 2011, 39, 4529-4540. [CrossRef]

83. Pearce, G.K. UF/MF pre-treatment to RO in seawater and wastewater reuse applications: A comparison of energy costs. Desalination 2008, 222, 66-73. [CrossRef]

84. Hussein, H.; Lambert, L.A. A Rentier State under Blockade: Qatar's Water-Energy-Food Predicament from Energy Abundance and Food Insecurity to a Silent Water Crisis. Water 2020, 12, 1051. [CrossRef]

85. Dare, A.; Mohtar, R.H. Farmer perceptions regarding irrigation with treated wastewater in the West Bank, Tunisia, and Qatar. Water Int. 2018, 43, 460-471. [CrossRef]

86. Shomar, B.; Darwish, M.; Rowell, C. What does Integrated Water Resources Management from Local to Global Perspective Mean? Qatar as a Case Study, the Very Rich Country with No Water. Water Resour. Manag. 2014, 28, 2781-2791. [CrossRef]

87. Yale Environment 360 Wall Street Begins Trading Water Futures as a Commodity. Available online: https://e360.yale.edu/digest/ wall-street-begins-trading-water-futures-as-a-commodity (accessed on 27 December 2020).

88. Lund, P.C.; Business Opportunities in Qatar-Agriculture and Aquaculture. Innovation Norway Middle East (IN). 2019. Available online: https:/ / www.norwep.com/content/download/38988/285622/version/2/file/2019+IN+Qatar+Business+ opportunities.pdf (accessed on 24 November 2020). 
89. Moustafa, A.T. Potential of Protected Agriculture and Hydroponics for Improving the Productivity and Quality of High Value Cash Crops in Qatar; Technical Assistance Program for the Qatar National Food Security Program (QNFSP); Task No 8; International Center for Agricultural Research in the Dry Areas (ICARDA): Beirut, Lebanon, 2010.

90. Alkhalidi, A.; Khawaja, M.K.; Abusubaih, D. Energy efficient cooling and heating of aquaponics facilities based on regional climate. Int. J. Low Carbon Technol. 2019, 15, 287-298. [CrossRef]

91. Ghani, S.; El-Bialy, E.M.A.A.; Bakochristou, F.; Rashwan, M.M.; Abdelhalim, A.M.; Ismail, S.M.; Ben, P. Experimental and numerical investigation of the thermal performance of evaporative cooled greenhouses in hot and arid climates. Sci. Technol. Built Environ. 2020, 26, 141-160. [CrossRef]

92. Bersani, C.; Ouammi, A.; Sacile, R.; Zero, E. Model Predictive Control of Smart Greenhouses as the Path towards Near Zero Energy Consumption. Energies 2020, 13, 3647. [CrossRef]

93. Amery, H.; Haddad, M. Ethical and Cultural Dimensions of Water Reuse: Islamic Perspectives. In Urban Water Reuse Handbook, 1st ed.; Eslamian, S., Ed.; CRC Press: Boca Raton, FL, USA, 2015; p. 1177.

94. Al-Thani, R.F.; Yasseen, B.T. Phytoremediation of polluted soils and waters by native Qatari plants: Future perspectives. Environ. Pollut. 2020, 259, 113694. [CrossRef]

95. Gairola, S.; Bhatt, A.; El-Keblawy, A. A perspective on potential use of halophytes for reclamation of salt-affected lands. Wulfenia J. 2015, 22, 88-97.

96. Bierman-Lytle, P. Economic Sustainability for Halophyte Cash Farms in Urban Environments. In Mangrove Ecosystems of Asia; Faridah-Hanum, I., Latiff, A., Hakeem, K.R., Ozturk, M., Eds.; Springer: New York, NY, USA, 2014; pp. 343-371. Available online: http:/ /link.springer.com/chapter/10.1007/978-1-4614-8582-7_16 (accessed on 13 January 2021).

97. Böer, B.; Khan, M.A.; Koyro, H.W.; Marcum, K.B. Prospects of Environmentally Friendly Farms for Food Security in Hot and Dry Coastal Areas Based on Seawater Irrigation and Wasteproducts-An Inspirational Proposal. In Sabkha Ecosystems; Volume V: The Americas, Khan, M.A., Boër, B., Özturk, M., Clüsener-Godt, M., Gul, B., Breckle, S.W., Eds.; Springer International Publishing: Cham, Switzerland, 2016; pp. 1-10. Available online: http://link.springer.com/chapter/10.1007/978-3-319-27093-7_1 (accessed on 13 January 2021).

98. Ben Hamed, K.; Magné, C.; Abdelly, C. From Halophyte Research to Halophytes Farming. In Sabkha Ecosystems, Tasks for Vegetation Science; Khan, M.A., Böer, B., Oztürk, M., Al Abdessalaam, T.Z., Clûsener-Godt, M., Gul, B., Eds.; Springer Science and Business Media: Dordrecht, The Netherlands, 2014; Volume 47.

99. Jed Brown, J.; Glenn, E.P.; Smith, S.E. Feasibility of Halophyte Domestication for High-Salinity Agriculture. In Sabkha Ecosystems, Tasks for Vegetation Science; Khan, M.A., Böer, B., Oztürk, M., Al Abdessalaam, T.Z., Clûsener-Godt, M., Gul, B., Eds.; Springer Science and Business Media: Dordrecht, The Netherlands, 2014; Volume 47.

100. Ghazanfar, S.A.; Altundag, E.; Yaprak, A.E.; Osborne, J.; Tug, G.N.; Vural, M. Halophytes of Southwest Asia. In Sabkha Ecosystems, Tasks for Vegetation Science; Khan, M.A., Böer, B., Oztürk, M., Al Abdessalaam, T.Z., Eds.; Springer Science and Business Media: Dordrecht, The Netherlands, 2014; Volume 47.

101. Loughland, R.A.; Qasam, A.; Burwell, B. Research and Development with Seawater and Halophytic Plants for Sustainable Saline Agro Systems in the Arabian Gulf. In Sabkha Ecosystems, Tasks for Vegetation Science; Khan, M.A., Böer, B., Oztürk, M., Al Abdessalaam, T.Z., Clûsener-Godt, M., Gul, B., Eds.; Springer Science and Business Media: Dordrecht, The Netherlands, 2014; Volume 47.

102. Jed Brown, J.; Cybulska, I.; Chaturvedi, T.; Thomsen, M.H. Halophytes for the Production of Liquid Biofuels. In Sabkha Ecosystems, Tasks for Vegetation Science; Khan, M.A., Böer, B., Oztürk, M., Al Abdessalaam, T.Z., Clûsener-Godt, M., Gul, B., Eds.; Springer Science and Business Media: Dordrecht, The Netherlands, 2014; Volume 47.

103. Böer, B.; Huot, C.; Sutcliffe, M. Floating Mangroves: The Solution to Reduce Atmospheric Carbon Levels and Land-Based Marine Pollution? In Sabkha Ecosystems, Tasks for Vegetation Science; Khan, M.A., Böer, B., Oztürk, M., Al Abdessalaam, T.Z., Clûsener-Godt, M., Gul, B., Eds.; Springer Science and Business Media: Dordrecht, The Netherlands, 2014; Volume 47.

104. Böer, B.; Ajmal Khan, M.; Marcum, K.B. World Halophyte Garden: Economic Dividends with Global Significance. In Sabkha Ecosystems, Tasks for Vegetation Science; Khan, M.A., Böer, B., Oztürk, M., Al Abdessalaam, T.Z., Clûsener-Godt, M., Gul, B., Eds.; Springer Science and Business Media: Dordrecht, The Netherlands, 2014; Volume 47.

105. Fita, A.; Rodríguez-Burruezo, A.; Boscaiu, M.; Prohens, J.; Vicente, O. Breeding and Domesticating Crops Adapted to Drought and Salinity: A New Paradigm for Increasing Food Production. Front. Plant Sci. 2015, 6, 978. [CrossRef] [PubMed]

106. Garcia, C.L.; Dattamudi, S.; Chanda, S.; Jayachandran, K. Effect of Salinity Stress and Microbial Inoculations on Glomalin Production and Plant Growth Parameters of Snap Bean (Phaseolus vulgaris). Agronomy 2019, 9, 545. [CrossRef]

107. Abdelaziz, M.E.; Abdelsattar, M.; Abdeldaym, E.A.; Atia, M.A.M.; Mahmoud, A.W.M.M.; Saad, M.M.; Heribert, H. Piriformospora indica alters $\mathrm{Na}+/ \mathrm{K}+$ homeostasis, antioxidant enzymes and LeNHX1 expression of greenhouse tomato grown under salt stress. Sci. Hortic. 2019, 256. [CrossRef]

108. Duchemi, E.; Wegmuller, F.; Legault, A.M. Urban agriculture: Multi-dimensional tools for social development in poor neighbourhoods. Field Actions Sci. Rep. 2008, 1, 43-51.

109. Van Veenhuizen, R. Profitability and Sustainability of Urban and Peri-Urban Agriculture; Agricultural Management, Marketing and Finance Occasional Paper; FAO: Rome, Italy, 2007.

110. De Zeeuw, H. Cities, Climate Change and Urban Agriculture. Urban Agric. Mag. 2011, 25, 39-42. 
111. Grichting, A. A productive permaculture campus in the desert: Visions for Qatar University. Future Food J. Food Agric. Soc. 2017, $5,21-33$.

112. Lakhdar, A.; Rabhi, M.; Ghnaya, T.; Montemurro, F.; Jedidi, N.; Abdelly, C. Effectiveness of compost use in salt-affected soil. J. Hazard. Mater. 2009, 171, 29-37. [CrossRef]

113. Melikoglu, M.; Lin, C.S.K.; Webb, C. Analysing global food waste problem: Pinpointing the facts and estimating the energy content. Cent. Eur. J. Eng. 2013, 3, 157-164. [CrossRef]

114. Planning and Statistics Authority in Qatar. Qatar Environment Day 2016; Planning and Statistics Authority: Doha, Qatar, 2016.

115. General Secretariat for Development Planning. Qatar National Vision 2030; General Secretariat for Development Planning: Doha, Qatar, 2008.

116. Qatar University Research and Graduate Studies. Available online: http://www.qu.edu.qa/research/sustainable-developmentcenter/research-programs/food-\&-Water-Security-Program (accessed on 28 September 2020).

117. Qatar National Research Fund Research Programs. Available online: https://www.qnrf.org/en-us/Funding/ResearchPrograms/Thematic-and-Grand-Challenges-Research-Program/QNRF-MME-Joint-Funding (accessed on 28 September 2020).

118. Gulf Times Qatar. Available online: https://www.gulf-times.com/story/613702/MME-announces-investment-projects-toproduce-vegetables-in-greenhouses (accessed on 28 September 2020).

119. Qatar Development Bank Financial Products. Available online: https://www.qdb.qa/en/Pages/Green-House-Financing.aspx (accessed on 28 September 2020).

120. Qatar Tribune Front. Available online: https://www.qatar-tribune.com/news-details/id/164815 (accessed on 28 September 2020).

121. Vicente-Vicente, J.L.; Piorr, A. Can a shift to regional and organic diets reduce greenhouse gas emissions from the food system? A case study from Qatar. Carbon Balance Manag. 2021, 16, 2. [CrossRef] 